\title{
Preliminary Report on the Second Season of the Konya-Ereğli Survey (KEYAR) 2014
}

\section{Çiğdem Maner}

\section{(2) OpenEdition \\ 1 Journals}

\section{Electronic version}

URL: http://journals.openedition.org/anatoliaantiqua/361

DOI: 10.4000/anatoliaantiqua.361

\section{Publisher \\ IFEA}

Printed version

Date of publication: 1 June 2015

Number of pages: $249-273$

ISBN: 9782362450600

ISSN: 1018-1946

\section{Electronic reference}

Çiğdem Maner, «Preliminary Report on the Second Season of the Konya-Ereğli Survey (KEYAR) 2014 », Anatolia Antiqua [Online], XXIII | 2015, Online since 30 June 2018, connection on 18 December 2020. URL : http://journals.openedition.org/anatoliaantiqua/361 ; DOI : https://doi.org/10.4000/ anatoliaantiqua.361 


\title{
ANATOLIA ANTIQUA ESKI ANADOLU
}

\author{
XXIII
}

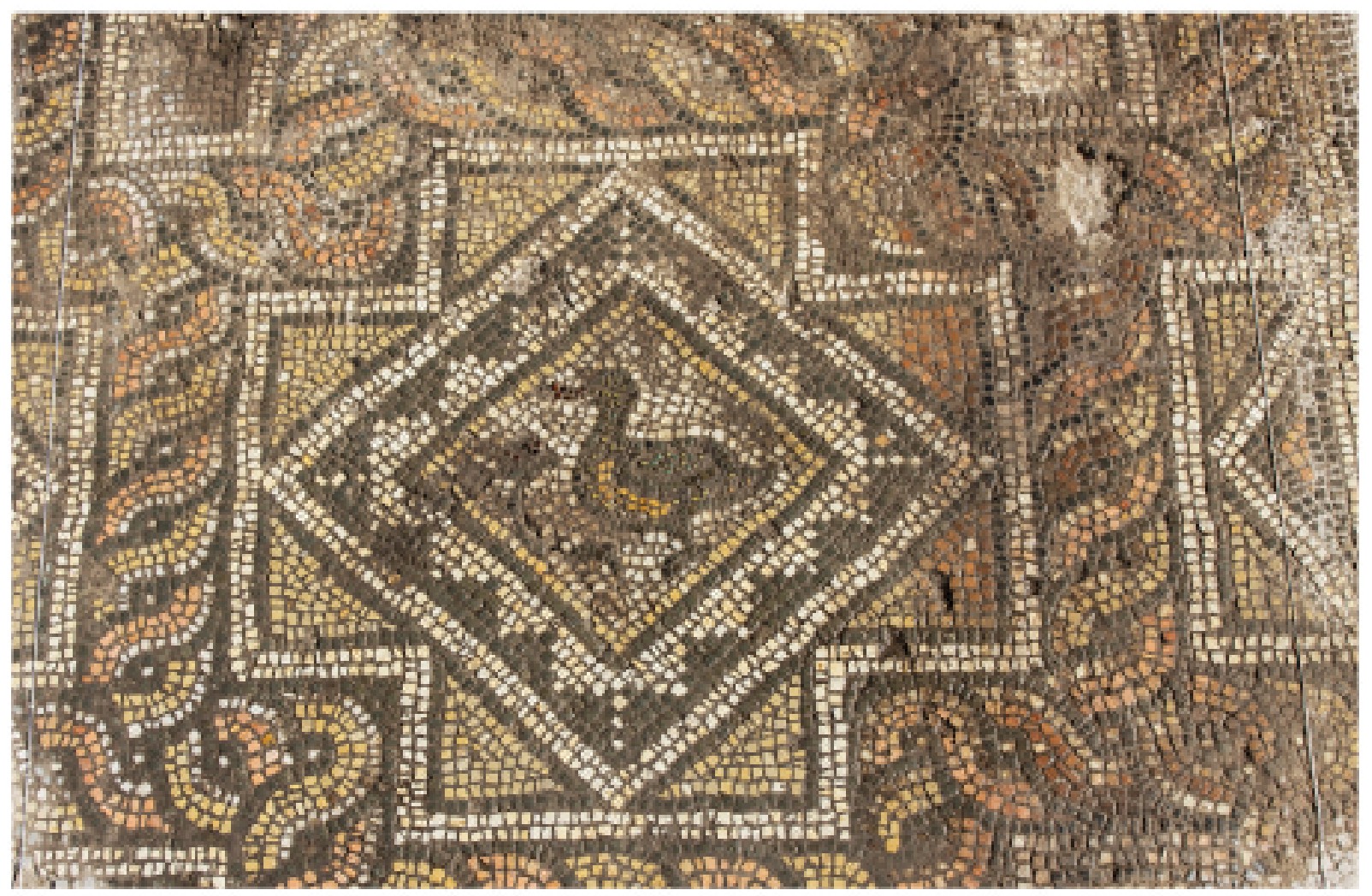

INSTITUT FRANC̣AIS D'ETUDES ANATOLIENNES GEORGES-DUMEZIL CNRS USR 3131 


\section{TABLE DES MATIERES}

Hélène BOUILLON,

On the anatolian origins of some Late Bronze egyptian vessel forms

Agneta FRECCERO,

Marble trade in Antiquity. Looking at Labraunda

Şehnaz ERASLAN,

Dionysus and Ariadne in the light of Antiocheia and Zeugma Mosaics

Ergün LAFLI et Gülseren KAN ŞAHIN,

Middle Byzantine ceramics from Southwestern Paphlagonia

Mustafa AKASLAN, Doğan DEMIRCİ et Özgür PERÇİN en collaboration avec Guy LABARRE, L'église paléochrétienne de Bindeos (Pisidie)

Anaïs LAMESA,

La chapelle des Donateurs à Soğanlı, nouvelle fondation de la famille des Sképidès

Martine ASSENAT et Antoine PEREZ,

Localisation et chronologie des moulins hydrauliques d'Amida. A propos d'Ammien Marcellin,

XVIII, 8,11

Helke KAMMERER-GROTHAUS,

$»$ Ubi Troia fuit«

Atzik-Köy - Eine Theorie von Heinrich Nikolaus Ulrichs (1843)

CHRONIQUES DES TRAVAUX ARCHEOLOGIQUES EN TURQUIE, 2015

Sami PATACI et Ergün LAFLI,

Surveys in Ardahan on the turkish-georgian borderline in 2013 and 2014

Çĭ̆dem MANER,

Preliminary report on the second season of the Konya-Ereğli survey (KEYAR) 2014

Dominique BEYER, Can KARAVUL, Françoise LAROCHE-TRAUNECKER et Aksel TiBBET,

Rapport préliminaire sur les travaux de la mission archéologique de Zeyve Höyük-Porsuk 2014

Jean-Charles MORETTI avec la collaboration de Nicolas BRESCH, Isabel BONORA,

Jean-Jacques MALMARY et Olivier RISS,

Claros, le temple d'Apollon : travaux réalisés en 2014

Olivier HENRY et Erika ANDERSSON, Christophe BOST, Ömür Dünya ÇAKMAKLI, Angela COMMITO, Mélissa CORMIER-HUGUET, Peter DE STAEBLER, Pierre DUPONT, Duygu ERGENÇ, Axel FREJMAN, Banu KEPENEK, Pascal LEBOUTEILLER, Haral NILSSON, Felipe ROJAS, Baptiste VERGNAUD, 


\section{Çiğdem MANER*}

\section{PRELIMINARY REPORT ON THE SECOND SEASON OF THE KONYA-EREĞLİ SURVEY (KEYAR) ${ }^{1} 2014$}

The second season of the Konya Ereğli survey project (KEYAR) was conducted from June 7 - July 7, 2014 with the permission of the Ministry of Culture and Tourism General Directorate of Museums and Antiquities. Ali Haydar Atalar from the Kayseri Archaeology Museum was our representative from the Ministry of Culture and Tourism Directorate of Museums and Antiquities. The project was generously supported by Koç University's College of Social Sciences and Humanities, Koç University Seed Fund (SF 00013), Ereğli Municipality, AVIS and Demireller Tesisleri. I would like to thank especially the director of the Ereğli Museum, Mr. Mahmut Altuncan, the mayor of Ereğli, Mr. Özkan Özgüven, and his deputy, Mrs. Zuhal Savaş, for their endless help and support. I am also grateful to Mrs. Sadiye Kaya, who has been driving us safely for two seasons through the southeastern Konya Plain, Mr. Hilmi Erel Muhtar of Pir Ömer Mahallesi in Ereğli, Pınar Özyürek from Koç University and Assistant Professor Caner Güney from Istanbul Technical University for their help and support. The survey team consisted of students from Koç University and Istanbul Technical University $^{2}$. I am grateful for their work and support.

The general aim of the five year project is to locate and survey the settlements of the Bronze and Iron Ages in the southeast provincial towns of Konya, namely, Ereğli, Halkapınar, Emirgazi and Karapinar $^{3}$. All of these provincial towns are under the supervision of the Ereğli Museum. Minor surveys were conducted by James Mellaart in the $1950 \mathrm{~s}^{4}$ and by Semih Güneri ${ }^{5}$ in the 1980s in Ereğli and Karapinar. However, these surveys did not aim to survey the whole area of these four provincial towns, only just a few major and obvious höyüks. This led to the fact that Ereğli, as well as Karapınar, were only partially surveyed, and Emirgazi and Halkapınar, not at all. Hence, to understand the settlement distribution during the Bronze and Iron Ages of the southeast corner of Konya, a survey of the whole region was necessary.

In 2013, the survey of the provincial town of Ereğli began (Map 1). During the two week survey, fourteen settlements and two tumuli were determined. Twelve of these settlements were new discoveries. In addition to the survey, small finds in the Ereğli Museum which date to the Bronze and Iron Ages, and which are from the region, have started to be published ${ }^{6}$. Recently, a spool-shaped, decorated clay object and the lower part of a Hittite bronze figurine have been published by the author ${ }^{7}$. Three more small finds dating to the Middle and Late Bronze Ages stored in the Ereğli Museum will be published in 2015. These objects give important clues especially about the Middle and Late Bronze Ages of the survey region and a match with the located settlements as possible find spots can be attempted.

We followed the same methodology as the 2013 survey $^{8}$. The Ministry of Culture and Tourism General

*) Çiğdem Maner, Koç University, Department of Archaeology and History of Art <cmaner@ku.edu.tr>

1) KEYAR: Konya Ereğli Yüzey Araştırması. Konya Ereğli Survey Project.

2) Aymesey Albay, Aysel Arslan, Hazel Bahar, Ece Bulak, Ayşe Bursalı, Muhip Çarkı, Betül Gaye Dinç, Elifgül Doğan, Sernaz Engin, Ahmet Yüksel Erel, Naide Gedikli, Yavuz Selim Güler, Alihan Keskin, Alican Kutlay, Aksel Mert Mağiya, Günce Pelin Öcgüden, Zeynep Özge Özdemir. I would like to thank Muhip Çarkı and Pelin Peker for their help in preparing the map and pottery charts.

3) For the research questions and results of the first survey season, see Maner 2014, also Maner in press a.

4) Mellaart 1955; 1958; 1963; 1965.

5) Güneri 1989-91; 1990.

6) I would like to thank the Museum director Mr. Mahmut Altuncan for his generous permission to publish these small finds.

7) Maner 2015a.

8) Maner 2014: 344-345. 


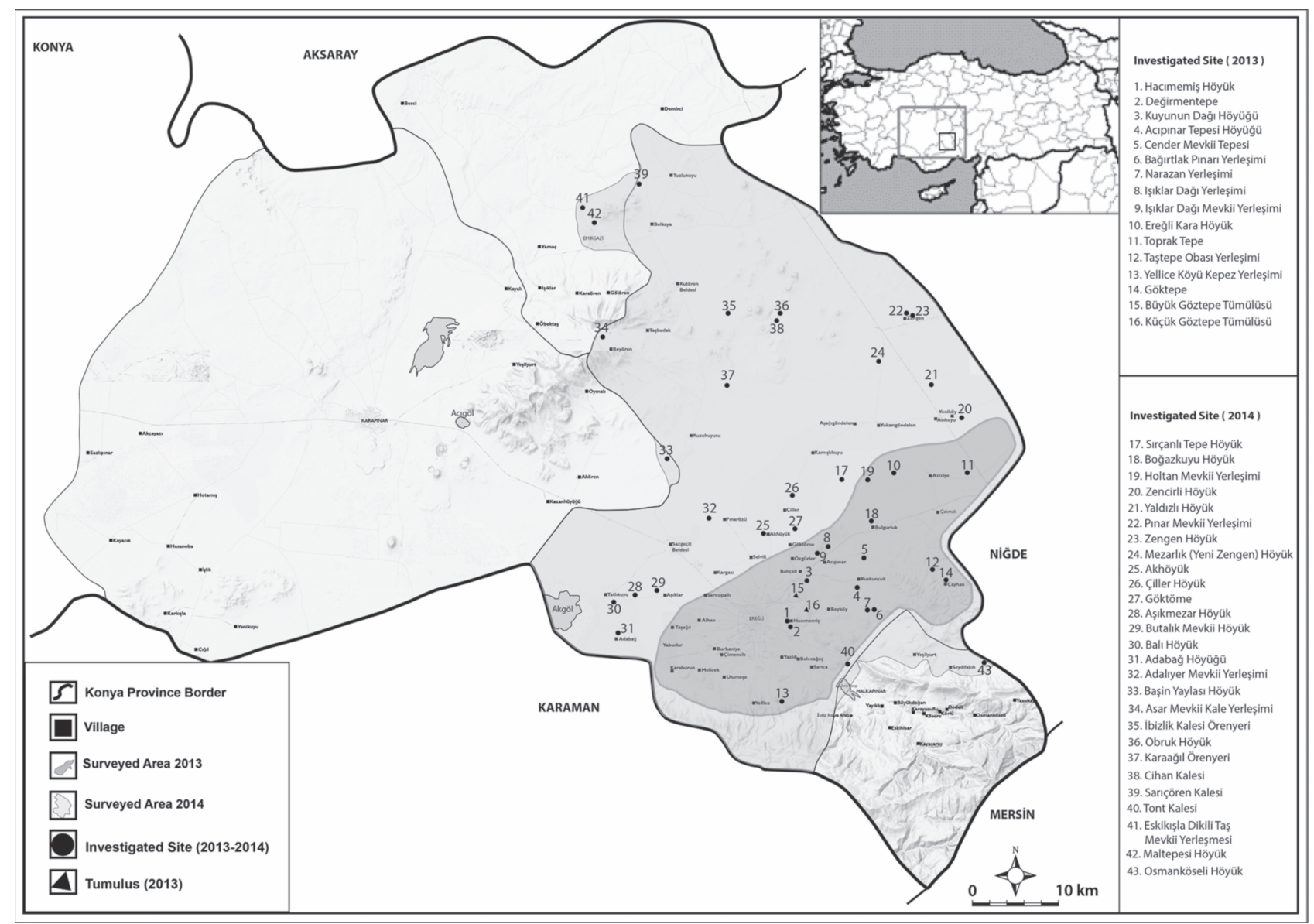

Map 1.

Directorate of Museums and Antiquities still continues to apply the regulation that does not allow the collection, storage and creation of pottery assemblages. Hence, we collected pottery from the surface, selected the significant ones from the results (Fig. 1), photographed (Fig. 2) and sketched (Fig. 3) them in situ and put them back where we collected them.

In 2014, the aim was to continue the survey of the Ereğli provincial town, which started in 2013 and also to begin the survey of the border districts between Ereğli and Halkapınar and between Ereğli and Emirgazi. During the one month survey in 2014 we visited the following villages of Ereğli: Bulgurluk, Aziziye, Yeniköy, Yukarı Göndelen, Acıkuyu, Aşağıgöndelen, Acıkuyu, Zengen, Obruk, Çukurkuyu, Kutören, Belkaya, Kızılgedik, Taşbudak, Beyören, Deveağıl, Karaağıl, Kuzukuyusu, Sazgeçit,Kargacı, Pınarözü, Selvili, Türkmen, Çiller, Kamışlıkuyu, Akhüyük, Göktöme, Özgürler, Aş1klar, Tatlıkuyu, Taşağıl, Adabağ, Büyükdede, Gaybı, Yıldız, Orhaniye, Belice, Gökçeyazı and Taştepe Obası. In addition, we surveyed a höyük in Halkapınar in a village

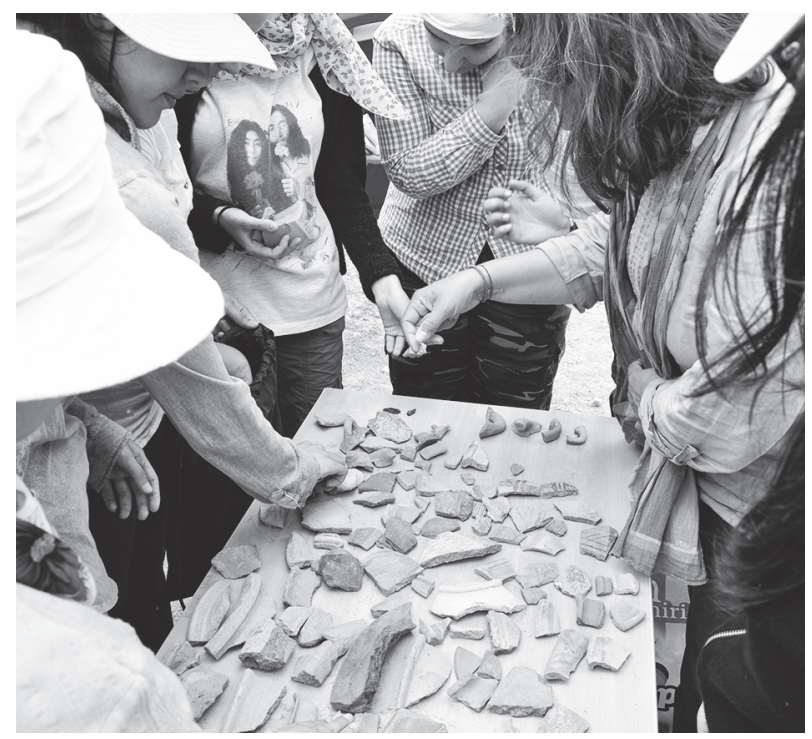

Fig. 1 : Pottery selection during the survey. 


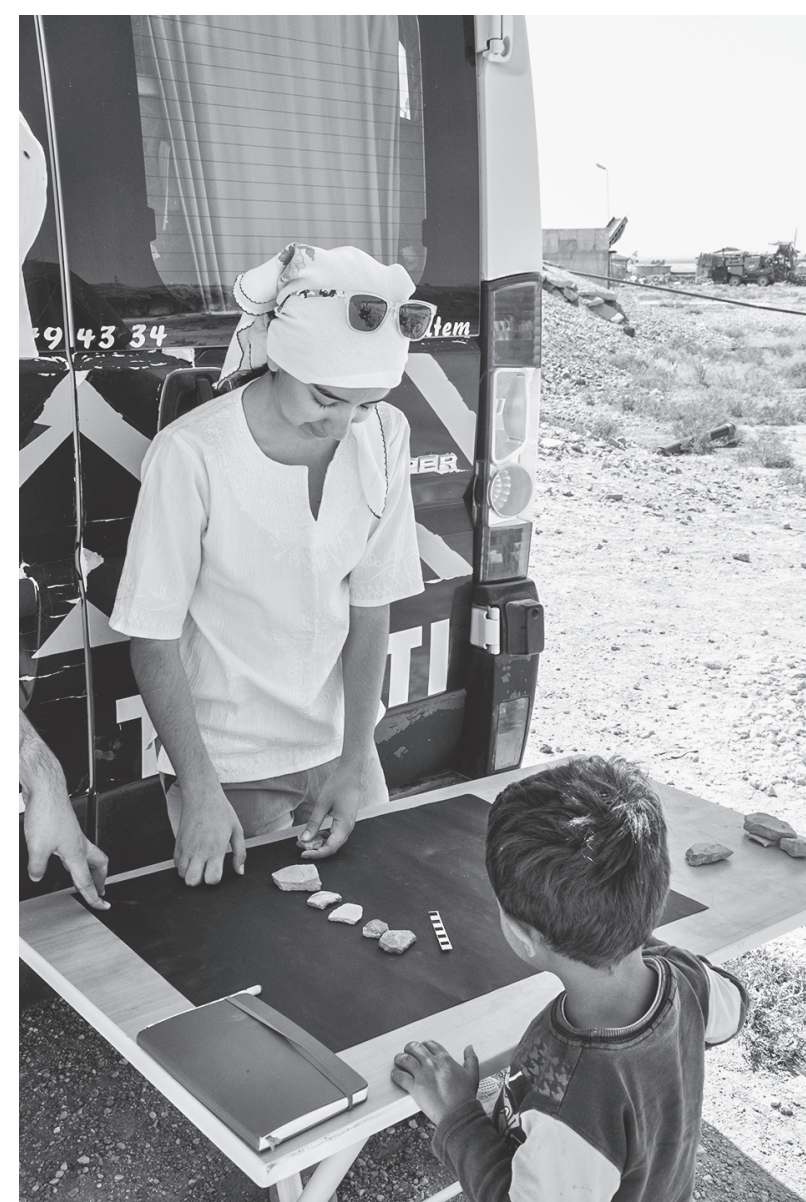

Fig. 2 : Photographing the pottery during the survey.
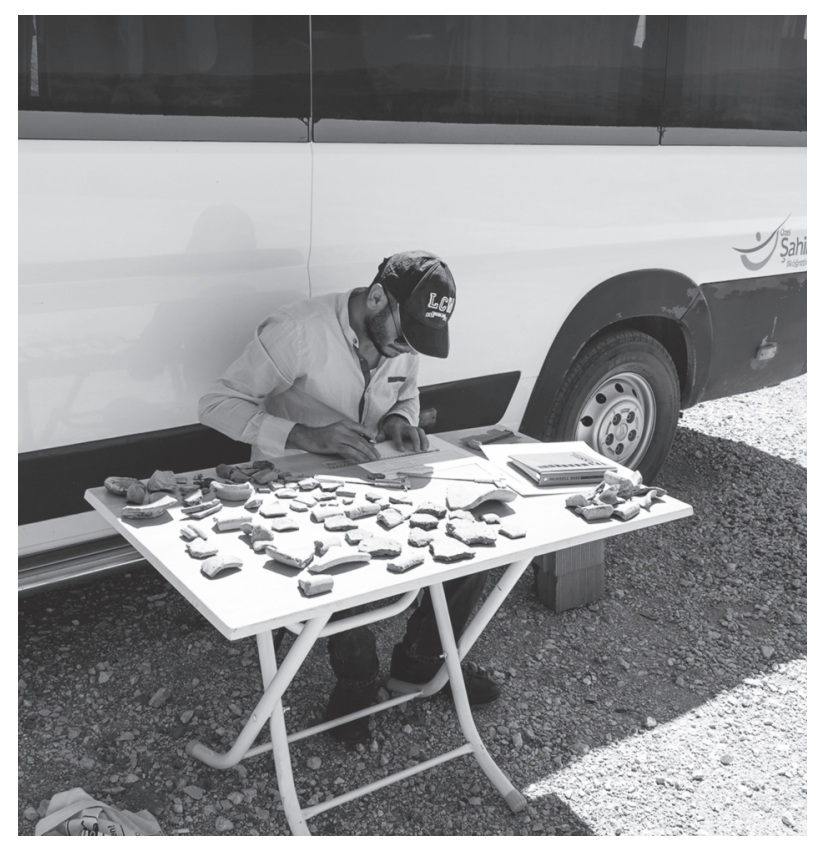

Fig. 3 : Sketching the pottery on the site. called Seydifakil1, and in Emirgazi short visits were paid to Eskikışla Mevkii and Dikilitaş Mevkii. Just southeast of Eskikışla Mevkii, a höyük (Maltepesi) was located and surveyed.

During the 2014 season, we identified 27 settlements (Map 1, Table 1). The settlements and material remains will be explained in the following section.

Table 1: Investigated Settlements of the 2014 Survey Season.

\begin{tabular}{|c|c|c|c|}
\hline $\mathbf{N}^{0}$ & $\begin{array}{l}\text { Name of } \\
\text { Settlement }\end{array}$ & $\begin{array}{l}\text { Province and } \\
\text { Village Name }\end{array}$ & Altitude \\
\hline 17 & Sirçanlı Tepe & $\begin{array}{l}\text { Ereğli, Bulgurluk, } \\
\text { Kamıșlıkuyu Köyü }\end{array}$ & $1041 \mathrm{~m}$ \\
\hline 18 & Boğazkuyu Höyük & Ereğli, Bulgurluk & $1072 \mathrm{~m}$ \\
\hline 19 & $\begin{array}{l}\text { Holtan Mevkii } \\
\text { Yerleşimi }\end{array}$ & Ereğli, Bulgurluk & $1056 \mathrm{~m}$ \\
\hline 20 & Zencirli Höyük & Ereğli, Yeniköy & $1052 \mathrm{~m}$ \\
\hline 21 & Yaldızlı Höyük & Ereğli, Yeniköy & $1042 \mathrm{~m}$ \\
\hline 22 & $\begin{array}{l}\text { Pınar Mevkii } \\
\text { Yerleşimi }\end{array}$ & Ereğli, Eski Zengen & $1093 \mathrm{~m}$ \\
\hline 23 & Zengen Höyük & Ereğli, Eski Zengen & $1038 \mathrm{~m}$ \\
\hline 24 & Mezarlık (Yeni & Ereğli, Yeni Zengen & \\
\hline & Zengen) Höyük & Кӧуü & $1043 \mathrm{~m}$ \\
\hline 25 & Akhöyük & Ereğli, Akhüyük & $1021 \mathrm{~m}$ \\
\hline 26 & Çiller Höyük & Ereğli, Çiller & $1023 \mathrm{~m}$ \\
\hline 27 & Göktöme & Ereğli, Göktöme & $1023 \mathrm{~m}$ \\
\hline 28 & Aşıkmezar & Ereğgli, Aşıklar- & \\
\hline & Höyüğü & Tatlikuyu & $1009 \mathrm{~m}$ \\
\hline 29 & $\begin{array}{l}\text { Butalık Mevkii } \\
\text { Höyük }\end{array}$ & Ereğli, Aşıklar & $1011 \mathrm{~m}$ \\
\hline 30 & Balı Höyük & Ereğli, Tatlıkuyu & $1007 \mathrm{~m}$ \\
\hline 31 & Adabağ Höyüğ̆̈̈ & Ereğli, Adabağ & $1004 \mathrm{~m}$ \\
\hline 32 & $\begin{array}{l}\text { Adaliyer Mevkii } \\
\text { Yerleşimi }\end{array}$ & Ereğli, Pınarözü & $1017 \mathrm{~m}$ \\
\hline 33 & $\begin{array}{l}\text { Başin Yaylası } \\
\text { Höyük }\end{array}$ & Ereğli, Kuzukuyu & $1021 \mathrm{~m}$ \\
\hline 34 & $\begin{array}{l}\text { Asar Mevkii Kale } \\
\text { Yerleşimi }\end{array}$ & $\begin{array}{l}\text { Ereğli, Beyören, } \\
\text { Keklikören-Asar } \\
\text { Mevkii }\end{array}$ & $1526 \mathrm{~m}$ \\
\hline 35 & $\begin{array}{l}\text { İbizlik Kalesi } \\
\text { Örenyeri } \\
\text { (Çekin Kalesi) }\end{array}$ & Ereğli, Kutören & $1103 \mathrm{~m}$ \\
\hline 36 & Obruk Höyük & $\begin{array}{l}\text { Ereğli, Kutören, } \\
\text { Obruk Yaylası }\end{array}$ & $1050 \mathrm{~m}$ \\
\hline 37 & $\begin{array}{l}\text { Karaağıl Ören yeri } \\
\text { (Maşatca Höyük) }\end{array}$ & Ereğli, Karaağıl & $1047 \mathrm{~m}$ \\
\hline 38 & Cihan Kalesi & $\begin{array}{l}\text { Ereğli, Kutören, } \\
\text { Obruk yaylası üstü }\end{array}$ & $1085 \mathrm{~m}$ \\
\hline 39 & Sarıçören Kalesi & $\begin{array}{l}\text { Ereğli, Belkaya köyü } \\
\text { sinırında, Kötü Dağ } \\
\text { mevkiinde }\end{array}$ & $1192 \mathrm{~m}$ \\
\hline 40 & Tont Kalesi & $\begin{array}{l}\text { Ereğli, Gökçeyazı } \\
\text { Köyü }\end{array}$ & $1266 \mathrm{~m}$ \\
\hline 41 & Eskikışla Dikili Taş & $\begin{array}{l}\text { Mevkii yerleşmesi } \\
\text { Emirgazi, Eskikışla } \\
\text { (Kıcıkısla) }\end{array}$ & $1075 \mathrm{~m}$ \\
\hline 42 & Maltepesi Höyük & Emirgazi, Yunus Emre & \\
\hline & & Kale Mahallesi & $1266 \mathrm{~m}$ \\
\hline 43 & Osmanköseli Höyük & $\begin{array}{l}\text { Halkapınar, Seydifakı1ı } \\
\text { Köyü }\end{array}$ & $1445 \mathrm{~m}$ \\
\hline
\end{tabular}




\section{Sırçanlı Tepe Höyük (Map 1 No 17, Fig. 4)}

The settlement is located $c a .7 \mathrm{~km}$ northwest of Bulgurluk village and has been registered since 2003. It is a höyük settlement $c a .95 \mathrm{~m} \mathrm{x} 95 \mathrm{~m}$ large and $c a .1 .8 \mathrm{~m}$ high. No architectural features are preserved and no worked building blocks were seen. The plain around the höyük and also the höyük itself is used for agriculture. This led to the destruction and also to the reduction of the settlement size.

Two small fragments of obsidian tools were discovered. The number of pottery sherds on the mound were limited. Among them were hand-formed body sherds, probably Early Chalcolithic, also pottery from Middle Iron Age and Roman periods were found.

\section{Boğazkuyu Höyük (Map 1 No 18, Fig. 5-7)}

In 2013, we had visited Bulgurluk; however, we entered the village from the east and couldn't locate any settlement. During this year's survey season, we approached the village from the west, from the Ereğli-Adana highway, and passed through the village. At the northern end, a medium-sized höyük appeared (Fig. 5). The höyük and also the plain around it is used for agriculture. The höyük stands $1.7 \mathrm{~km}$ north of Bulgurluk. The höyük is called 'Boğazkuyu Höyük' by the local people and is not registered. It is an almond-shaped settlement mound, which measures (N-S) $414 \mathrm{~m} \mathrm{x} \mathrm{(E-W)} 183 \mathrm{~m}$ and is around $3 \mathrm{~m}$ high. The settlement is located inside a fertile alluvial plain and has an important strategic location. Since the whole höyük is used for agriculture and the barley was around $1.5 \mathrm{~m}$ high during the survey period and covered the whole area, only a few pottery sherds could be collected. At the southern edge of the höyük, in between the barley, a $0.7 \mathrm{~m}$ long, $0.45 \mathrm{~m}$ wide and $0.55 \mathrm{~m}$ high worked stone block was discovered (Fig. 6). One side is flat and the other dome-shaped. It is likely the cover of a small tomb. On one of the short sides it has a domeshaped cavity. As the mound was covered with belly-high barley, no other worked stones or architectural features were discovered. Among the pottery were pieces from the Middle Bronze Age (Fig. 7: 1), Middle Iron Age (Fig. 7: 2), Hellenistic, Roman and Byzantine Periods. Also, a few obsidian tool fragments were found.

\section{Holtan Mevkii Yerleșimi (Map 1 № 19, Fig. 8)}

This settlement is located $6 \mathrm{~km}$ north of Bulgurluk and was shown to us by a villager who had discovered pithoi fragments in this area. The settlement is not a höyük, but a flat settlement, and is not registered. The area is used as a field, which made surveying impossible. The size of the settlement could not be measured, as only very few pottery fragments were found. No worked stones or architectural remains were observed. Among the pottery fragments which lay on the ground were Roman pottery sherds and green glazed ones, which probably date to the Byzantine Period.

\section{Zencirli Höyük (Map 1 № 20, Fig. 9-11)}

Zencirli Höyük, along with Ereğli Karahöyük ${ }^{9}$, is an important settlement just to the north of the Cilician Gates. The settlement has an important strategic location, connecting south-north and westeast and is also located within very fertile alluvial land. The höyük (Fig. 9) is $2.5 \mathrm{~km}$ east of Yeniköy, a village of Ereğli, which is on the border with Niğde. The höyük was registered in 2012 and the registration process is still in progress. It was surveyed by J. Mellaart ${ }^{10}$ and S. Güneri ${ }^{11}$.

The höyük is (N-S) $377 \mathrm{~m} \mathrm{x}(\mathrm{E}-\mathrm{W}) 327 \mathrm{~m}$. The top is much narrower than the höyük itself and is only (N-S) $100 \mathrm{~m} \times(\mathrm{E}-\mathrm{W}) 100 \mathrm{~m}$. The highest part of the höyük is around $6 \mathrm{~m}$ high. On the slopes, on top, and surrounding it are several large and small animal holes, mostly from foxes, as well as illicit excavations. The höyük consists of three artificial terraces, which probably mark the extension of different settlement periods. At the edges of the northern and northeastern slopes are 2-3 m high small mounds (Fig. 10). The villagers say that once (around 100 years ago) there were tin workshops under these mounds. The pottery on these small, shallow mounds dates to the Middle Iron, Roman, Byzantine and Ottoman periods. Among them were also rounded pot sherds, which have rounded edges and generally are interpreted as lids. On the southern edge of the höyük are the foundations and remains of a rectangular building. According to the muhtar of Aşağıgöndelen village, the building functioned during the Republican Period as a caravanserai. The pottery and beads which were found in this building seem to be Late

10) Mellaart 1954: 192; 1955: 125, 130; 1958: 335; 1963: 209 № 93. Mellaart calls the settlement in his 1954 publication Sincirli Höyük. In his 1963 publication it is mentioned as Zencirli Höyük.

11) Güneri 1989-91: 99, 102. Güneri calls the settlement Zincirli Höyük, however it is registered as Zencirli Höyük by the authorities. 

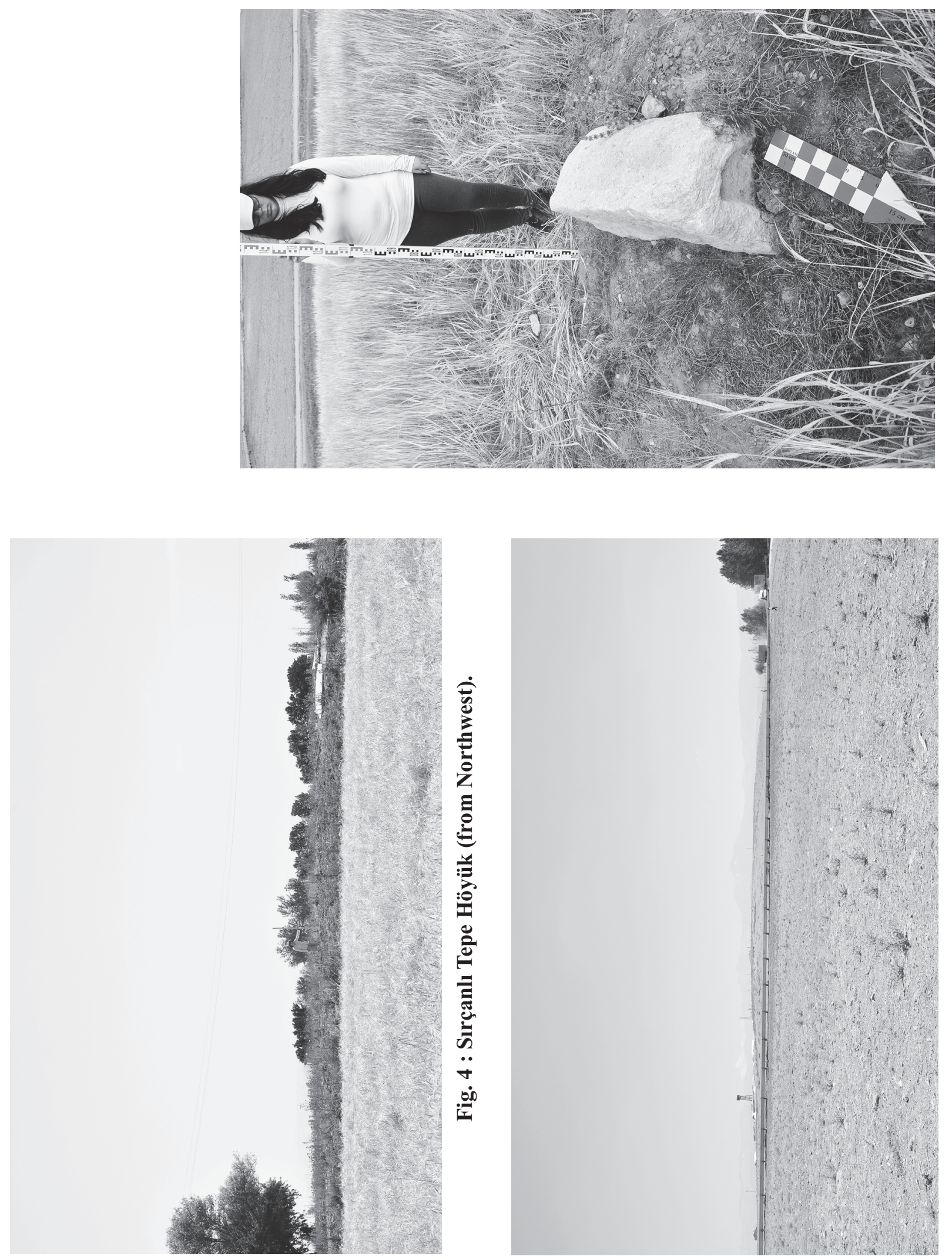

 

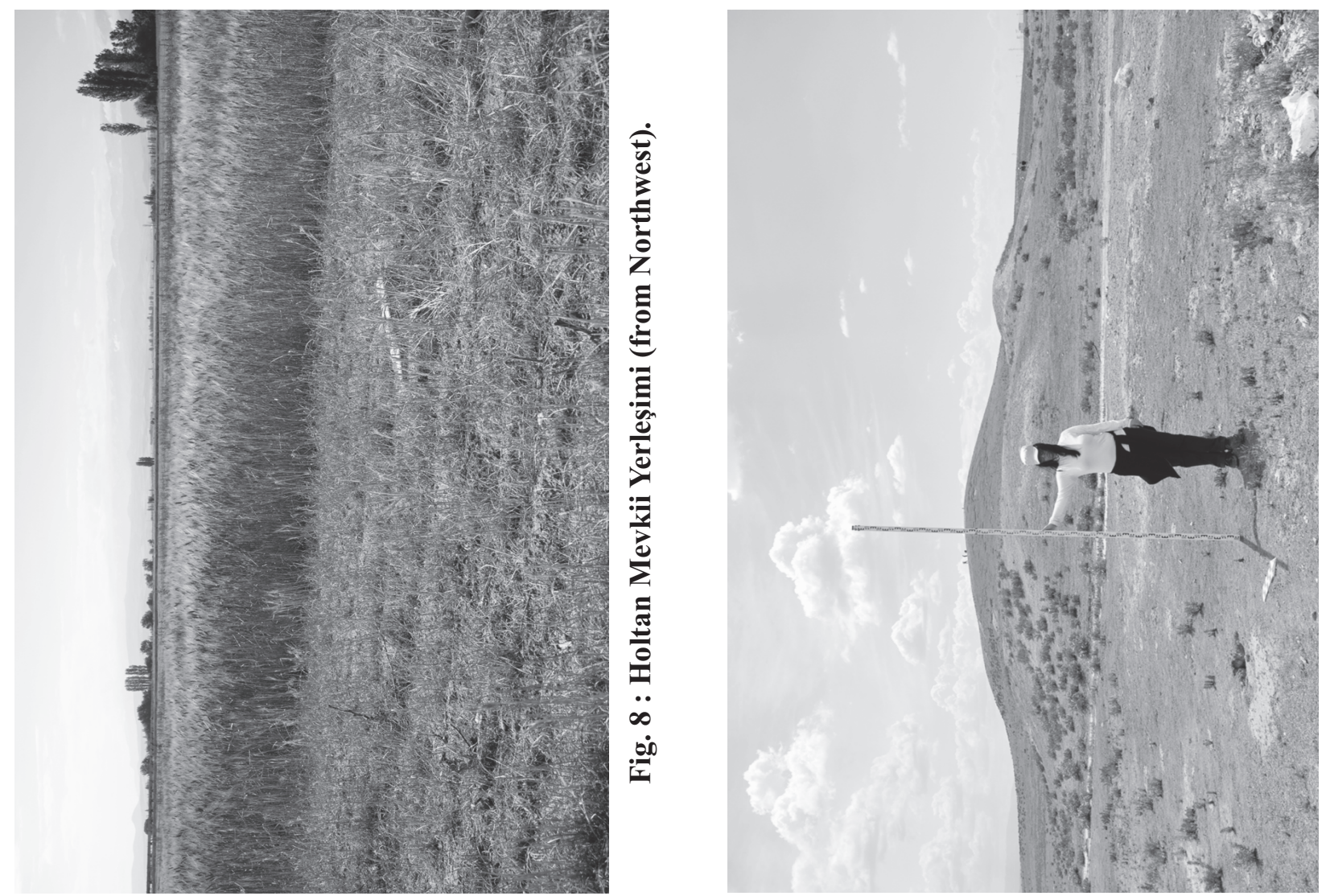

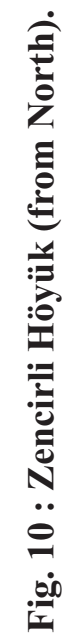
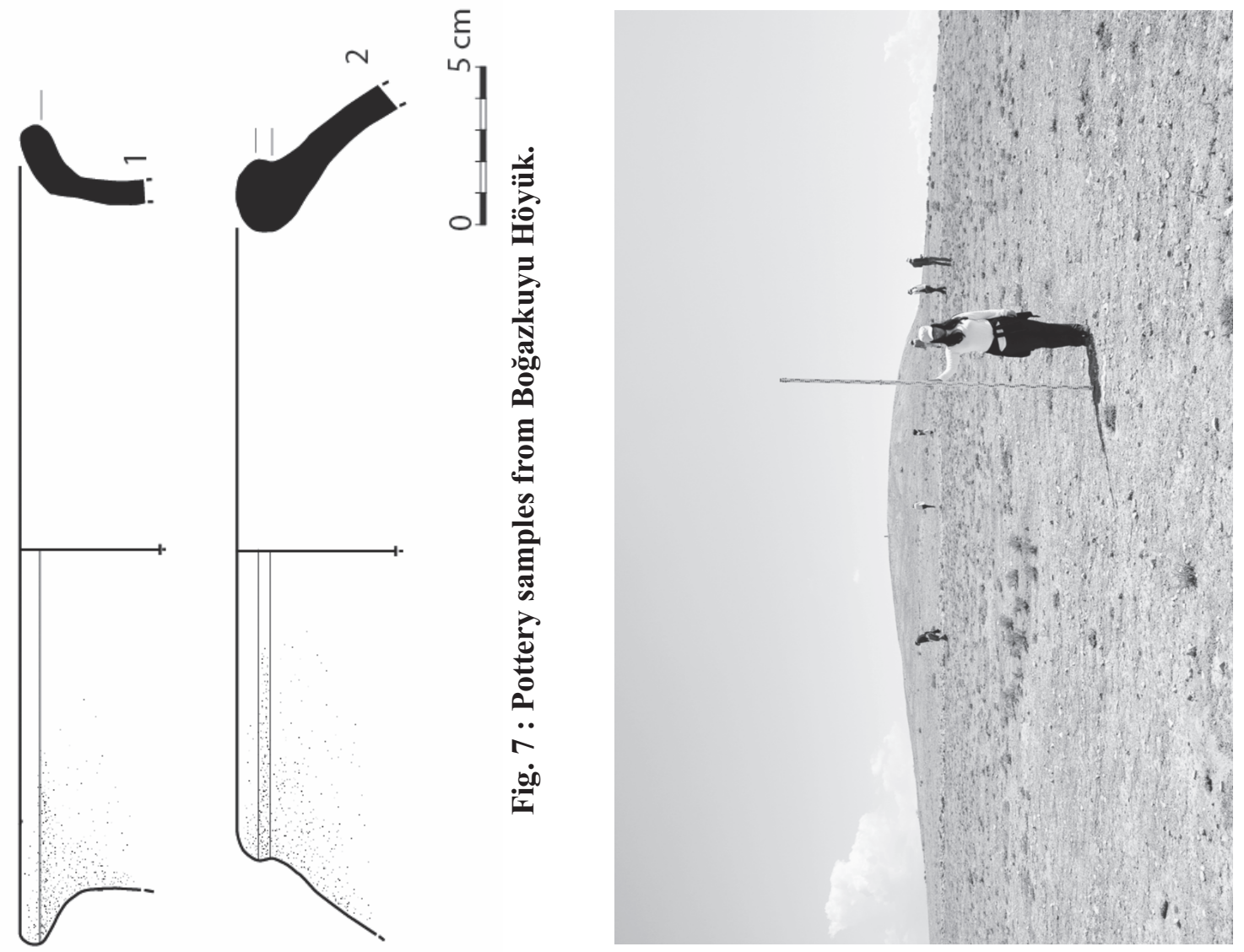

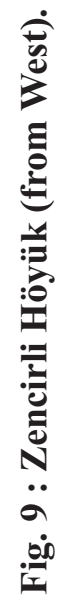



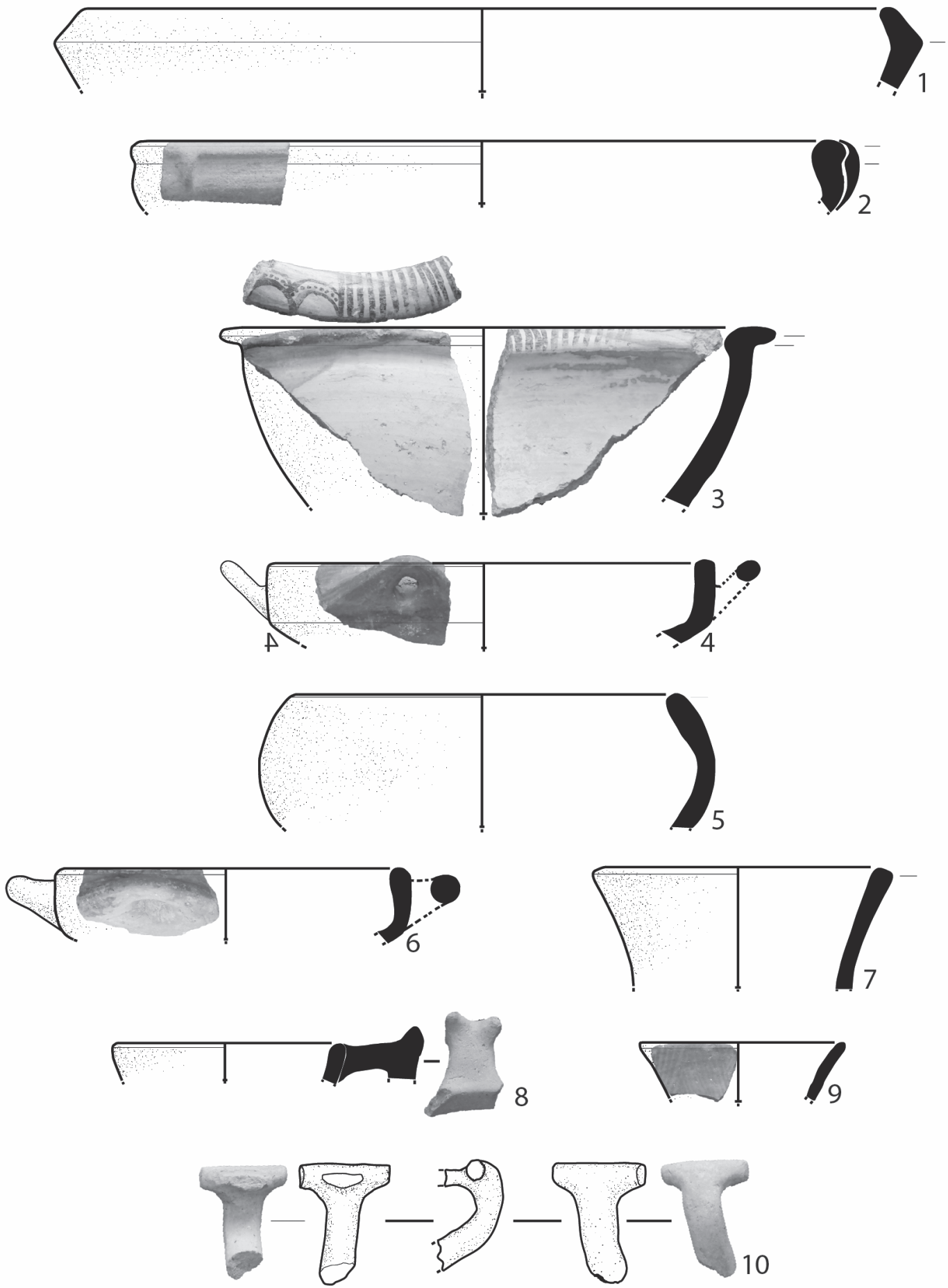

$\underline{0}-\underline{5} \mathrm{~cm}$

Fig. 11 : Zencirli Höyük: Pottery samples. 
Ottoman and Republican. Other than these foundations, no other architectural remains were discovered.

The pottery which was collected, especially on the southern and northern slopes, is very interesting and shows that Zencirli Höyük was occupied continuously from the Neolithic until the Byzantine Period. Neolithic, Chalcolithic and Early Bronze Age pottery sherds (Fig. 11: 5, 7, 9) were strayed over the mound. Mellaart mentions both Karum Period pottery and Cappadocian Ware at Zencirli Höyük ${ }^{12}$. During the 2014 survey season, several fragments of Middle Bronze Age pottery were found (Fig. 11: $1,4,6)$, among them were also two decorated Cappadocian Ware sherds and two horizontal handles (Fig. 11: 4, 6) which probably date to Karum II or $\mathrm{Ib}^{13}$. The red-burnished handle belongs to a twohandled bowl (Fig. 11: 4). Among the collected handles was also a fragment of a dear-shaped handle, which dates probably to the Middle or Late Bronze Age (Fig. 11: 8). A similar example of a deer-shaped handle was found at Alişar Höyük in Level $\mathrm{II}^{14}$.

Zencirli Höyük is $88 \mathrm{~km}$ south of Acemhöyük and $11 \mathrm{~km}$ southwest of Ereğli Karahöyük, which also has a Karum Period occupation. Zencirli Höyük and Ereğli Karahöyük were surely part of the Old Assyrian Trading networks. A bear-shaped stamp seal and an Old Babylonian cylinder sea ${ }^{15}$ on display in the Ereğli Museum, are from the Ereğli region, according to the entries in the museum database. Perhaps they were looted from these sites.

As Mellaart observed, the Bronze Age level settlements are covered by a thick Iron Age layer ${ }^{16}$. During our survey, we encountered the same phenomenon. In addition to Mellaart's remark, it is important to mention that very distinctive and important Iron Age pottery fragments were distributed over the mound (Fig. 11: 2, 10). Among them are several decorated rim fragments which have parallels with Porsuk Zeyve Höyük Level IV and Level $\mathrm{III}^{17}$. A painted body sherd with a wild goat motif has parallels with examples from Alişar IV ${ }^{18}$. Mellaart also observed that Alişar IV pottery was distributed over the mound ${ }^{19}$. Among the Middle Iron Age pottery were examples with compass-made circles (the compass hole is still visible) which are painted black on buff ware. This type of painted pottery was also found in Porsuk Zeyve Höyük Level IV ${ }^{20}$ and in Midas City ${ }^{21}$.

\section{Yaldızlı Höyük (Map 1 No 21, Fig. 12)}

This crescent-shaped settlement is a shallow höyük (Fig. 12) that extends over quite a large area and has been registered since 1988. It is located on the eastern side of the Adana-Ankara highway, 2 $\mathrm{km}$ north of the entrance to Yeniköy village. This settlement is on the same vertical axis as Zencirli Höyük. It is (N-S) $440 \mathrm{~m}-160 \mathrm{~m}$ x (E-W) $500 \mathrm{~m}$ $140 \mathrm{~m}$ large and $0.5-1 \mathrm{~m}$ high and is surrounded by dry, arid land, which is right now not used for agriculture. The survey showed that this settlement was occupied mainly during the Late Bronze Age, Middle and Late Iron Age, Roman, Byzantine and Seljuk periods. Several glazed pottery fragments and glass bracelet pieces were found. These glass bracelet fragments, in particular, suggest that there was likely a production center for these bracelets here.

\section{Pınar Mevkii Yerleşimi (Map 1 № 22, Fig. 13)}

Pınar Mevkii Yerleşimi (settlement) is a newly discovered settlement. It is on the way to Eski Zengen Höyük, $800 \mathrm{~m}$ northeast of the townhouse. On our way to Eski Zengen Höyük, we passed by an artificial pool with an entrance to a cave to the west. This cave is referred to as an underground town by the villagers. However, it wasn't possible to enter, as the entrance had collapsed. North of the pool, just next to the road, a shallow höyük is located on a natural rock slope (Fig. 13). The pottery dates to the Early and Middle Bronze Ages, Iron Age and the Roman period. Also, two obsidian tool fragments, an obsidian arrow and flint pieces were found.

\section{Zengen Höyük (Map 1 № 23, Fig. 14-16)}

Zengen Höyük (Fig. 14) has been a registered settlement since 1988 . The settlement is $500 \mathrm{~m}$

12) Mellaart 1958: 323, 335.

13) This type of handle is known, for example, from Alişar (Schmidt 1932: Pl. X; Von der Osten 1937: Fig. 219-220)

14) Schmidt 1932: 135 Fig. 168, also from Kültepe. In Kültepe, this type of handle belongs to two-handled bowls. For example, see Özgüç 2003: 177 Fig. 169.

15) Both objects are described and analyzed in forthcoming publications.

16) Mellaart 1955.

17) Dupré 1983, shaped like: Pl. 73 No 101, with inner rim decoration like Pl. 67 № 60 .

18) Schmidt 1932: Pl. 35 No b 1180:69, Pl. 3 № b 743: 10.

19) Mellaart 1955: map.

20) Dupré 1983: P1. 50 № 42, P1. 59 № 42.

21) Mellaart 1955: 118. 

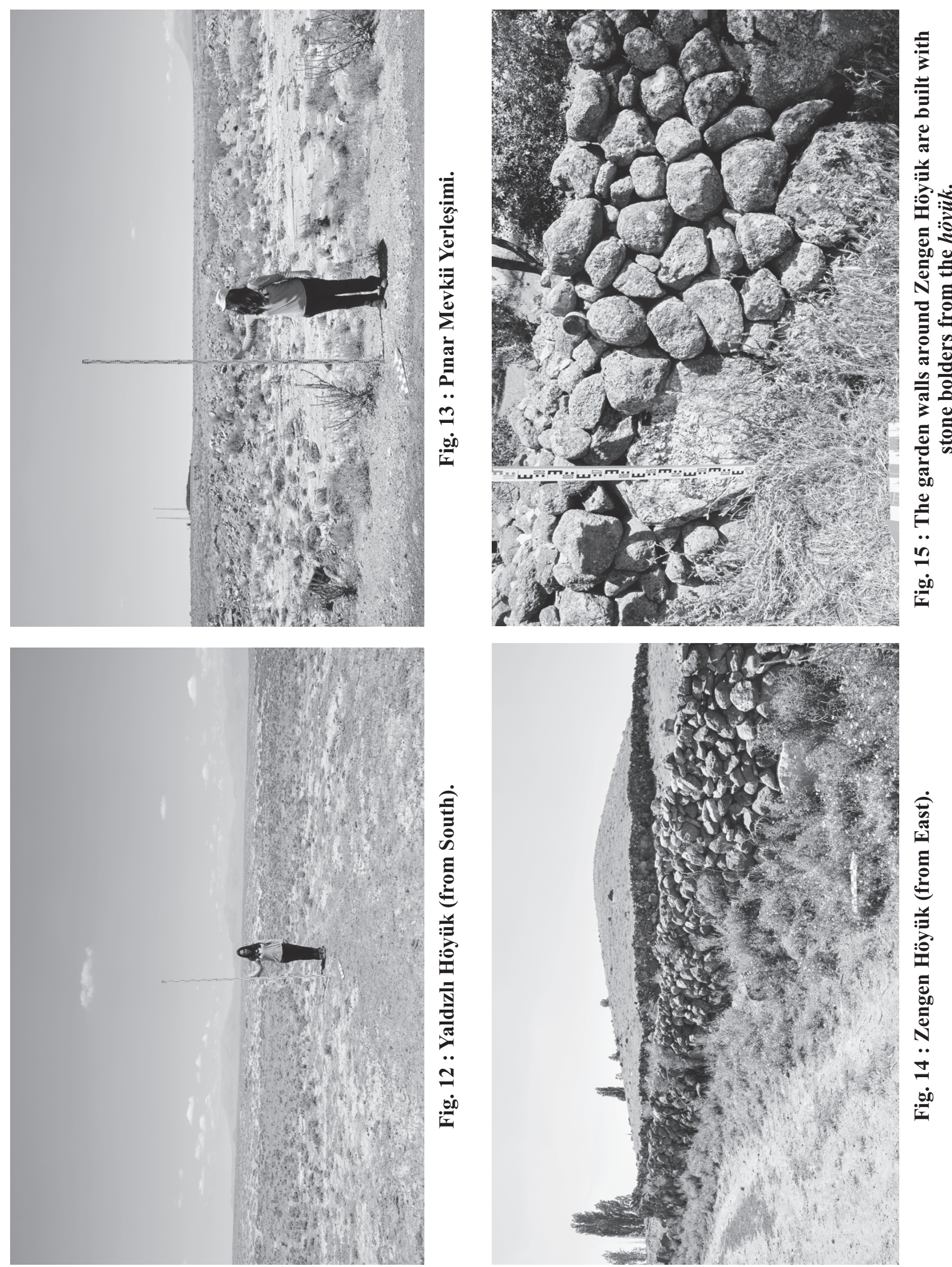

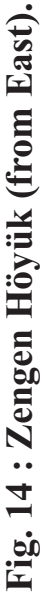




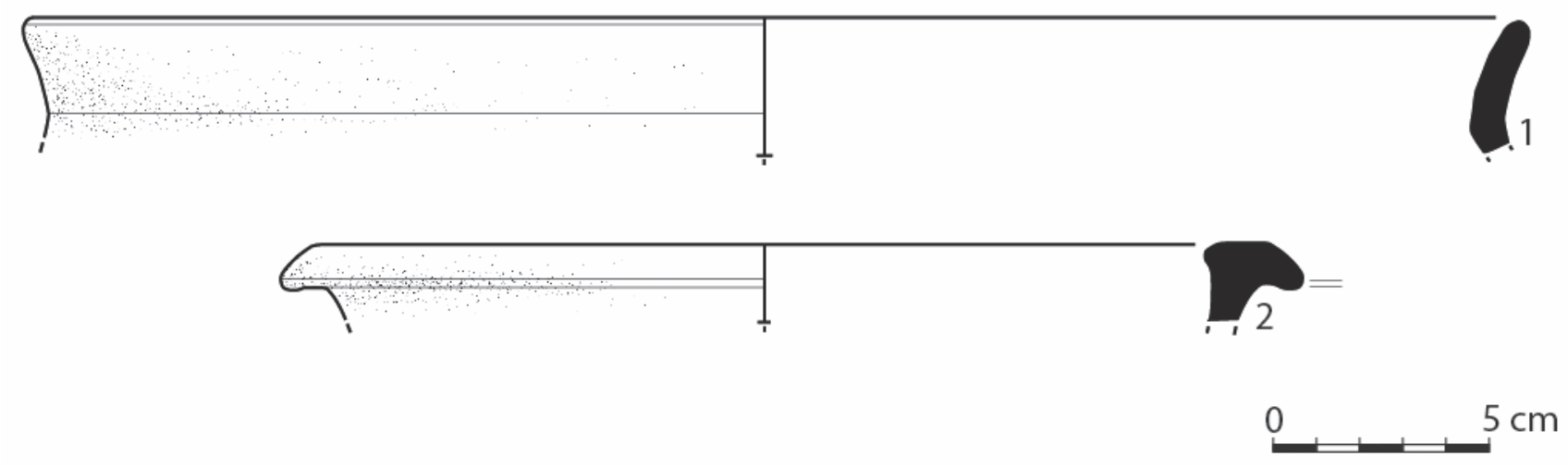

Fig. 16 : Zengen Höyük pottery samples.

southeast of Pınar Mevkii Yerleşimi. Güneri'22 surveyed this höyük as well. The settlement is located inside a fertile plain, which is divided into small garden units. The settlement is (N-S) $120 \mathrm{~m} \times(\mathrm{E}-\mathrm{W}) 110 \mathrm{~m}$ and around $6 \mathrm{~m}$ high. It consists of an acropolis and a lower level settlement, which have a height difference of around $3 \mathrm{~m}$. On the northeastern part are the remains of a stone foundation. These wall foundations are around $1 \mathrm{~m}$ wide and $5 \mathrm{~m}$ long and extend from north to south. The foundation is made of mediumsized stones. The villager who went with us to the höyük told us that once there were many stone foundations and remains of walls. The villagers dismantled these walls around 50-60 years ago and have built walls for their fields and gardens (Fig. 15). Among these walls are also large, roughly-shaped boulders, which might have been part of monumental structures. West of the höyük, inside a garden, a $0.8 \mathrm{~m}$ long and $0.5 \mathrm{~m}$ wide worked stone slab was discovered.

The majority of the pottery which was collected from the acropolis of the settlement and the northwestern side date to the Early (Fig. 16: 1) and Late Bronze Ages, Middle Iron Age (Fig. 16: 2), Hellenistic, Roman and Byzantine periods. Inside an illicit excavation hole, fragments of red-painted plaster, mudbrick pieces, and body sherds were found. Since there was no diagnostic pottery among the group, it is difficult to date them.

\section{Mezarlık Höyük (Yeni Zengen Höyük) (Map $1 \mathrm{~N}^{\circ}$ 24, Fig. 17)}

The Zengen village is divided by the AdanaAnkara highway. Zengen Höyük (Fig. 17) is located in the eastern part of the village and Yeni Zengen
Höyük in the western part. Yeni Zengen Höyük which lies south of the western part of the village is also known as Mezarlık Höyük (cemetery mound). The settlement has been a registered area since 1988. The höyük is about $12 \mathrm{~km}$ northwest of Yeniköy and $2.6 \mathrm{~km}$ south of Zengen village. It is around $2 \mathrm{~m}$ high and (N-S) $48 \mathrm{~m}$ x (E-W) $66 \mathrm{~m}$ large and is used partially for agriculture and also as a cemetery, hence the name 'Mezarlık Höyük'. Except for the tombs on the southern slope of the höyük, which belong to the villagers, no architectural features were discovered. The pottery ranges from Early-Middle-Late Bronze Age to Middle Iron Age, Roman and Byzantine periods.

\section{Akhöyük (Map 1 № 25, Fig. 18-20)}

Akhöyük is one of the biggest settlements in the Ereğli region. It has been a registered höyük since 1992. Güneri surveyed this mound as well ${ }^{23}$. The höyük is located $130 \mathrm{~m}$ northwest of the Akhöyük mosque. It is around (N-S) $210 \mathrm{~m} \times(\mathrm{E}-\mathrm{W}) 130 \mathrm{~m}$ and around $15 \mathrm{~m}$ high (Fig. 18-19). The ancient settlement was established on a natural rock plateau. The rock is known as 'Akhöyük taşı (stone)' by the inhabitants and is a sort of tuff stone. $112 \mathrm{~m}$ northeast of the höyük is a sulfur spring (Fig. 19). The intense smell of the sulfur can be detected from miles away. The southern slope and the top of the höyük have been used as a cemetery for several centuries. There are two rectangular tombs made of the indigenous Akhöyük tuff stone. One of them is on the southern slope and is $2.34 \times 1.04 \times 2.53 \mathrm{~m}$ large. The tomb on top is $2.34 \times 1.07 \times 2.60 \mathrm{~m}$ big and has stone decorations on both edges (şahide). No other archi- 

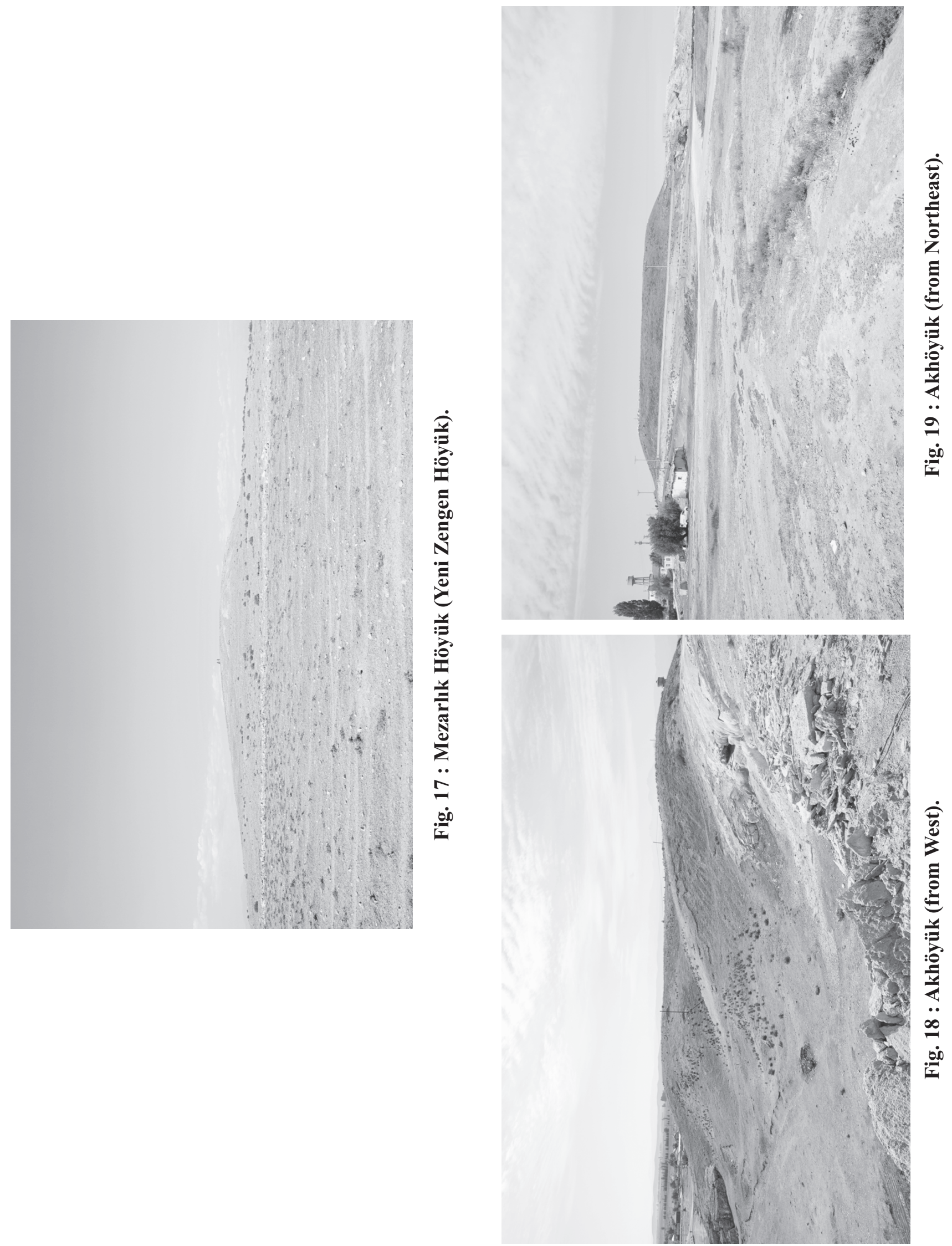


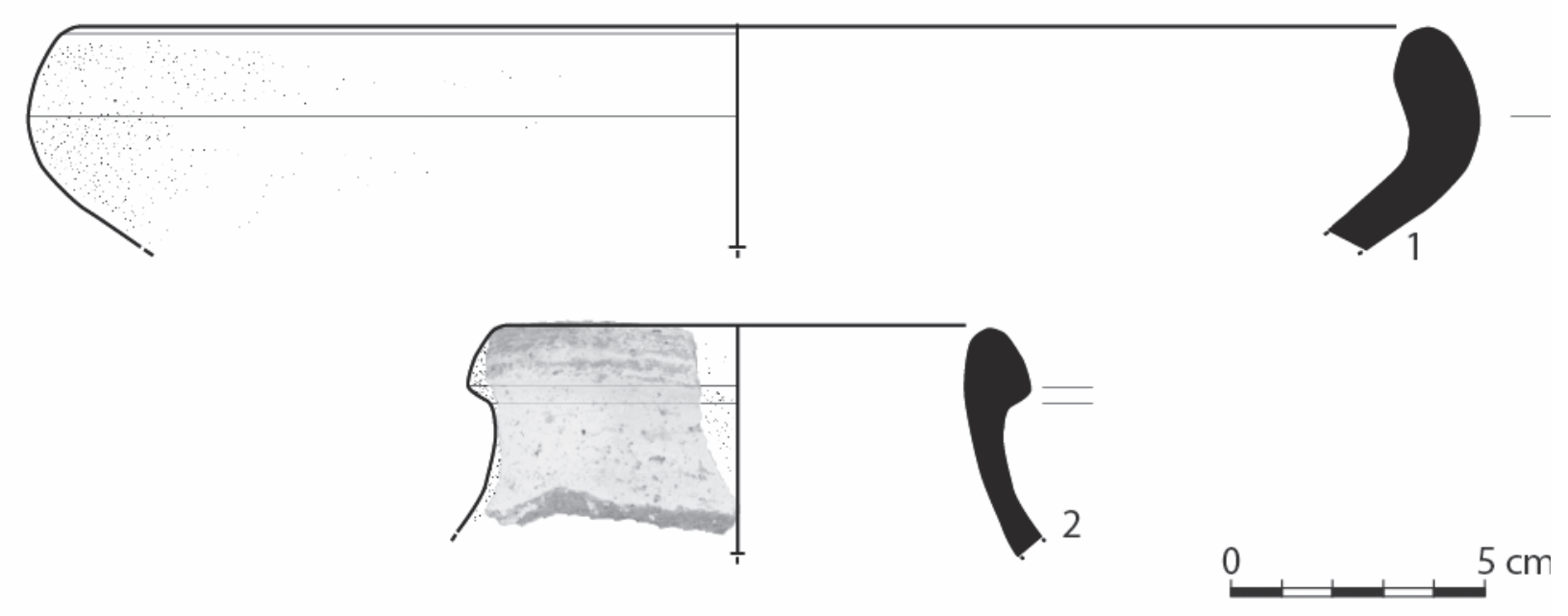

Fig. 20 : Akhöyük Pottery samples.

tectural features were recorded. A survey of the höyük was demanding, as it was covered with high grass, in addition to the tombs.

Fifty pieces of worked obsidian were found, among them seven blades and two arrowheads. The pottery showed that the site was inhabited from the Neolithic period until the Byzantine period. Pottery from the Neolithic, Chalcolithic, Early, Middle (Fig. 20: 1) and Late Bronze Ages, Middle Iron Age (Fig. 20: 2), Roman and Byzantine periods was found.

\section{Çiller Höyük (Map 1 № 26, Fig. 21-22)}

Çiller Höyük (Fig. 21) is, together with Ereğli Karahöyük, Zencirli Höyük and Akhüyük, one of the largest settlements in this region. They are all located on the same horizontal axis. The höyük is situated around $2 \mathrm{~km}$ northeast of Çiller Köyü mosque and has been registered since 1988. The mound was surveyed by Mellaart ${ }^{24}$ and Güneri ${ }^{25}$ as well.

The höyük is (N-S) $270 \mathrm{~m} \times(\mathrm{E}-\mathrm{W}) 260 \mathrm{~m}$ and around $8 \mathrm{~m}$ high. The ancient settlement consists of a höyük and a lower town. The northern part of the lower town is divided in two by the road from Akhüyük village to Çiller village. The eastern part was destroyed by small roads and irrigation canals. In the northeastern lower town were the tents of Syrian refugees who came here as seasonal workers. This has led to destruction and illicit excavations.
No architectural remains or worked stone blocks were discovered. Pottery was collected from the northern lower town. This shows a settlement history from the Neolithic, Chalcolithic, Early, Middle (Fig. 22: 1) and Late Bronze Ages, Iron Age (Fig. 22: 2), Hellenistic, Roman and Byzantine periods. Basket handle fragments with fingertip prints at the bottom were discovered. Similar types are known from the Middle Bronze Age levels of Beycesultan ${ }^{26}$.

$1.2 \mathrm{~km}$ northeast of Çiller Höyük, the villagers showed us the old village cemetery. Among the tombstones were ancient stones. One of the tombstones depicts two crosses and probably dates to the Byzantine period. Among the tombstones were also two Roman millstones (meta and catillus), as was found last season at Taştepe Obasi ${ }^{27}$.

Göktöme (Map $1 \mathrm{~N}^{\circ}$ 27, Fig. 23)

Göktöme $^{28}$ (Fig. 23) is a small settlement which is $3 \mathrm{~km}$ southeast of Çiller Köy Camii, and $0.65 \mathrm{~km}$ southeast of Ak Köprü, a Roman bridge (not registered) connected to a Roman road (not registered) which stretches from east to west. The höyük is (N-S) $75 \mathrm{~m} \mathrm{x}(\mathrm{E}-\mathrm{W}) 75 \mathrm{~m}$ and around $4 \mathrm{~m}$ high. On top are several large, deep illicit excavation holes. No remains of architecture were visible. Only a few sherds were found, which date to the Roman and Byzantine periods. This must be a small settlement connected to the Roman bridge. 
Fig. 21 : Çiller Höyük (from South).
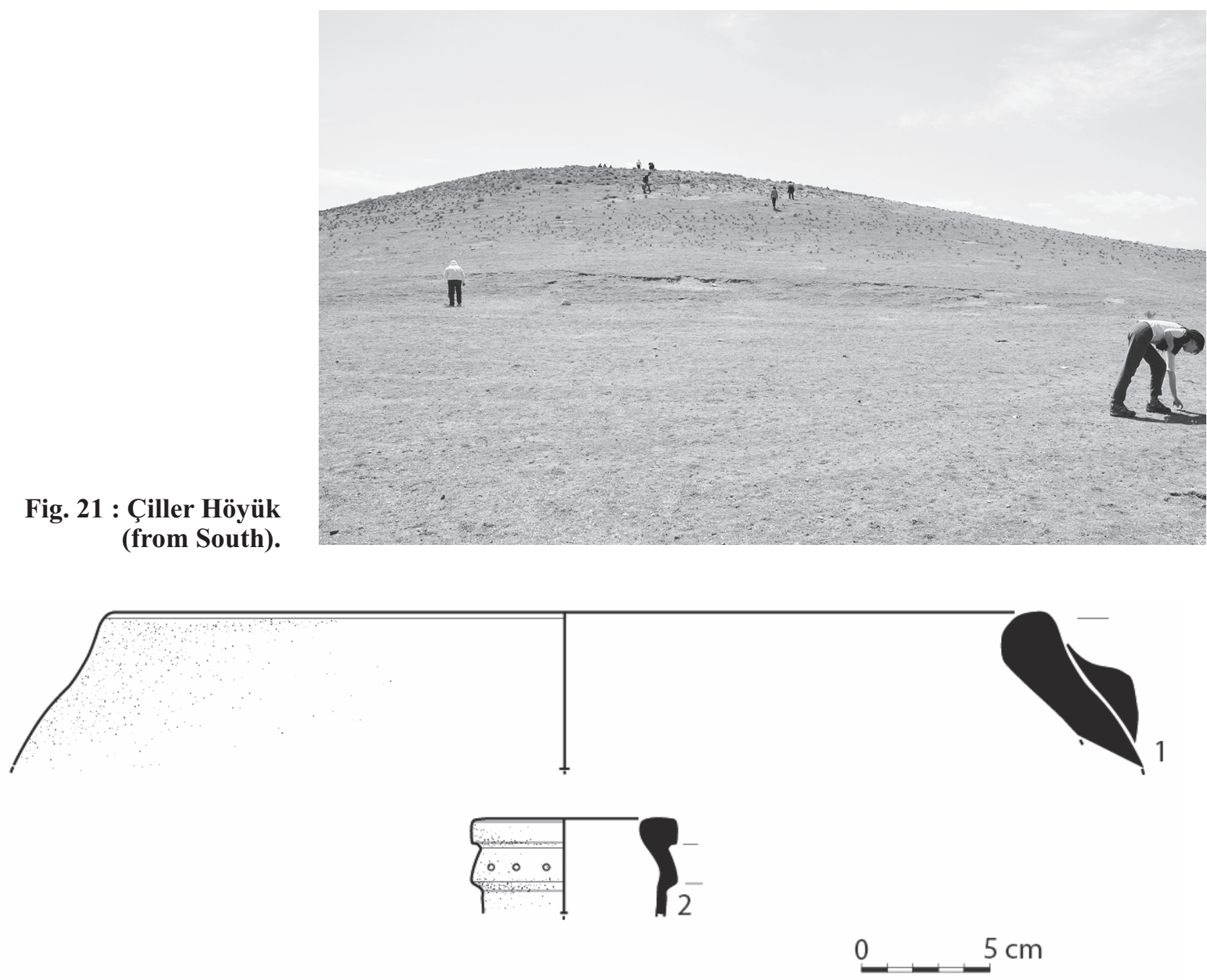

Fig. 22 : Çiller Höyük pottery samples.

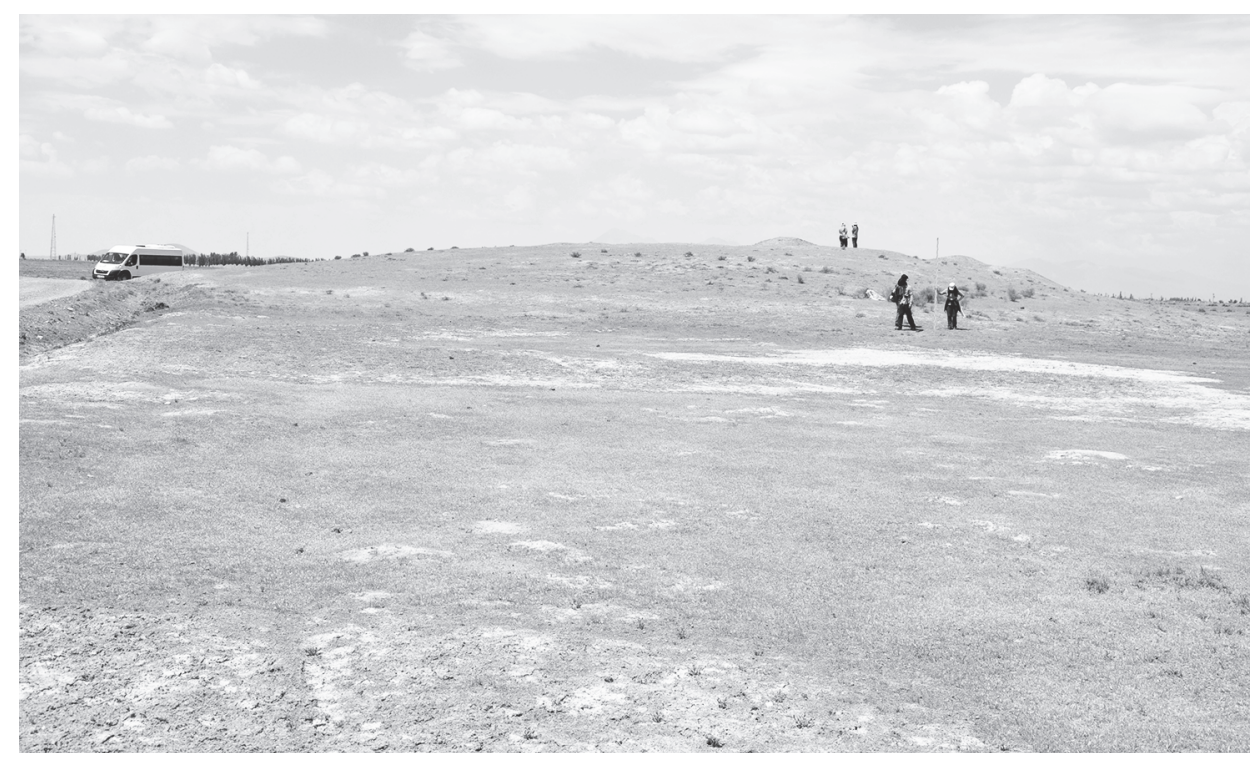

Fig. 23 : Göktöme. 


\section{Aşıkmezar Höyüğü (Kırhöyük)}

(Map $1 \mathrm{~N}^{\circ} 28$, Fig. 24)

This settlement is located between the villages of Aș1klar and Tatlıkuyu and was registered in 2012. Aşıkmezar Höyük (Fig. 24) is $3.23 \mathrm{~km}$ west of Aş1klar village and $80 \mathrm{~km}$ north of the main road. The höyük is $4 \mathrm{~m}$ high and (N-S) $150 \mathrm{~m} \mathrm{x}(\mathrm{E}-\mathrm{W})$ $160 \mathrm{~m}$. On the settlement, and also around it, no architectural remains were preserved. The collected pottery shows a wide range from the Early Bronze Age to Byzantine periods.

Butalık Mevkii Höyük (Map 1 № 29, Fig. 25)

This höyük (Fig. 25) is $1.2 \mathrm{~km}$ northwest of Aşılklar village and $2.25 \mathrm{~km}$ northeast of Aşı kmezar Höyük. It appears to be a flat settlement, although it is a höyük which lost its elevation due to agricultural activities. No architectural remains or worked stones were seen. The few collected pottery sherds date to the Roman period.

\section{Balı Höyük (Map 1 № 30, Fig. 26)}

Balı Höyük (Fig. 26) was shown to us by one of the villagers of Aș1klar village. It is located around $1.2 \mathrm{~km}$ southeast of Tatlikuyu village. Due to agricultural activities, this höyük is very shallow, around 0.5-1 m high, and (N-S) $160 \mathrm{~m} \mathrm{x} \mathrm{(E-S)} 160 \mathrm{~m}$. Several foxholes are spread over the ancient settlement, and it is covered with short, thorny bushes which made a survey almost impossible. The pottery sherds were on the mound and also spread across the fields. They date to the Middle Iron Age, Roman and Byzantine periods.

Adabağ Höyüğü (Map 1 No 31, Fig. 27)

Adabağ Höyügü (Fig. 27) is situated 1 km northeast of Adabağ village and was registered in 1996. This medium-sized höyük is (N-S) $150 \mathrm{~m} \times(\mathrm{E}-\mathrm{W})$ $150 \mathrm{~m}$ and $c a .5 \mathrm{~m}$ high. Its northeastern part was bulldozed to create a water canal and to remove dirt for construction. The northern tip of the höyük is cut by a road. No architectural remains were discovered, except for two rectangular-shaped and stone-framed structures on the southern slope, which supposedly are graves of the villagers. Pottery was mainly col- lected from the top, southwestern and eastern slopes. The northern part did not reveal much pottery due to deep bulldozer activity. The pottery ranges from the Early-Middle-Late Bronze Ages, Iron Age, Hellenistic, Roman and Byzantine periods.

A Grey Ware ram-shaped rython in the Ereğli Museum (Inv. No 1951) is supposed to have come from Adabağ Höyügüu, according to the museum entries $^{29}$. The rython is $7.6 \mathrm{~cm}$ long and $4.5 \mathrm{~cm}$ high and currently exhibited. It was acquired in 1988 by the Ereğli Museum ${ }^{30}$.

\section{Adalıyer Mevkii Yerleşimi \\ (Map $1 \mathrm{~N}^{\circ}$ 32, Fig. 28)}

This interesting flat settlement was shown to us by a resident of Pınarözü village. It came to his attention because it is close to his fields, and he saw people digging there at night. When we went there, we encountered several looted Roman graves. It is a flat settlement with a cemetery, with no elevation, like most of the Roman settlements in this region. The settlement is $2.1 \mathrm{~km}$ west of Pınarözü village, and the western side seems to be the settlement while the eastern side is the cemetery. The graves are mainly cist graves which are lined with slightlyworked, rectangular, flat stone slabs (Fig. 28). They are east-west oriented. The western part was covered with Roman and Byzantine pottery pieces. However, since the Roman Period is not included in our permit, we did not conduct any further investigations.

Başin Yaylası Höyük (Map 1 № 33, Fig. 29)

This ancient settlement (Fig. 29) is $4.75 \mathrm{~km}$ southeast of Kuzukuyu village. The settlement mound is $(\mathrm{N}-\mathrm{S}) 150 \mathrm{~m} \times(\mathrm{E}-\mathrm{W}) 300 \mathrm{~m}$ and stretches southeast to northeast across a hill. The southern slopes seems to be part of the settlement. The whole area is used for agriculture. At first sight, it looks like that there are two settlements. However, closer investigation showed that it is actually one höyük, which was divided in two by plough activity. Among the collected pottery sherds were Early, Middle and Late Bronze Age, Middle Iron Age, and Roman pieces. The settlement seems to be at an important strategic location, higher up on the hill and surrounded by fertile land.

29) It was bought from a villager who said that it comes from Adabağ.

30) The publication about the rython is forthcoming. The rython was already depicted in the MA thesis by Ali Haydar Atalar titled "Ereğli Herakleia Kybistra Antik Kenti" submitted to Kafkas University in 2009. The rython is mentioned and depicted on pages 7, 67, and 87. However, Atalar dates it to the Early Bronze Age, which is incorrect. The Grey Ware is typical of the Iron Age. 

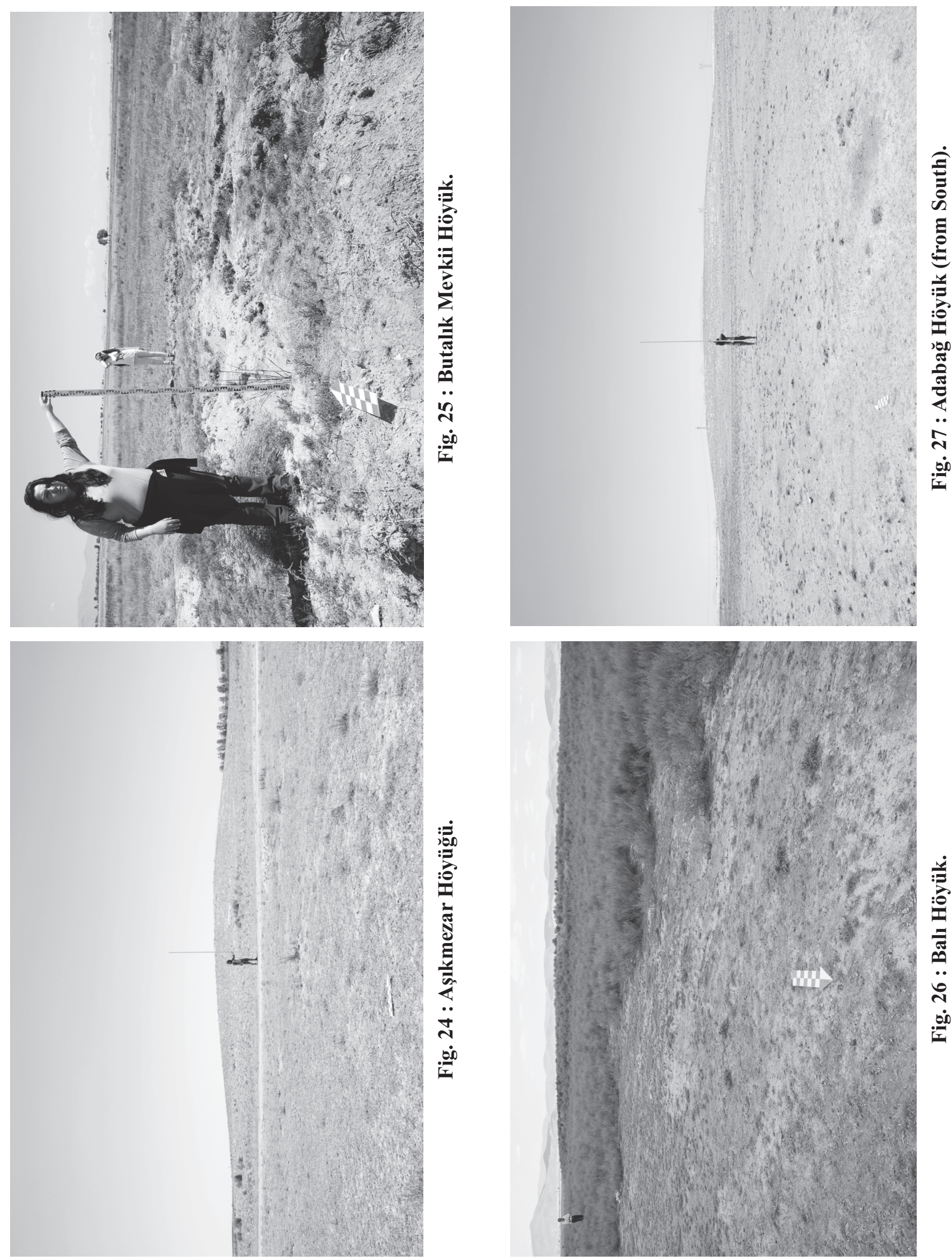


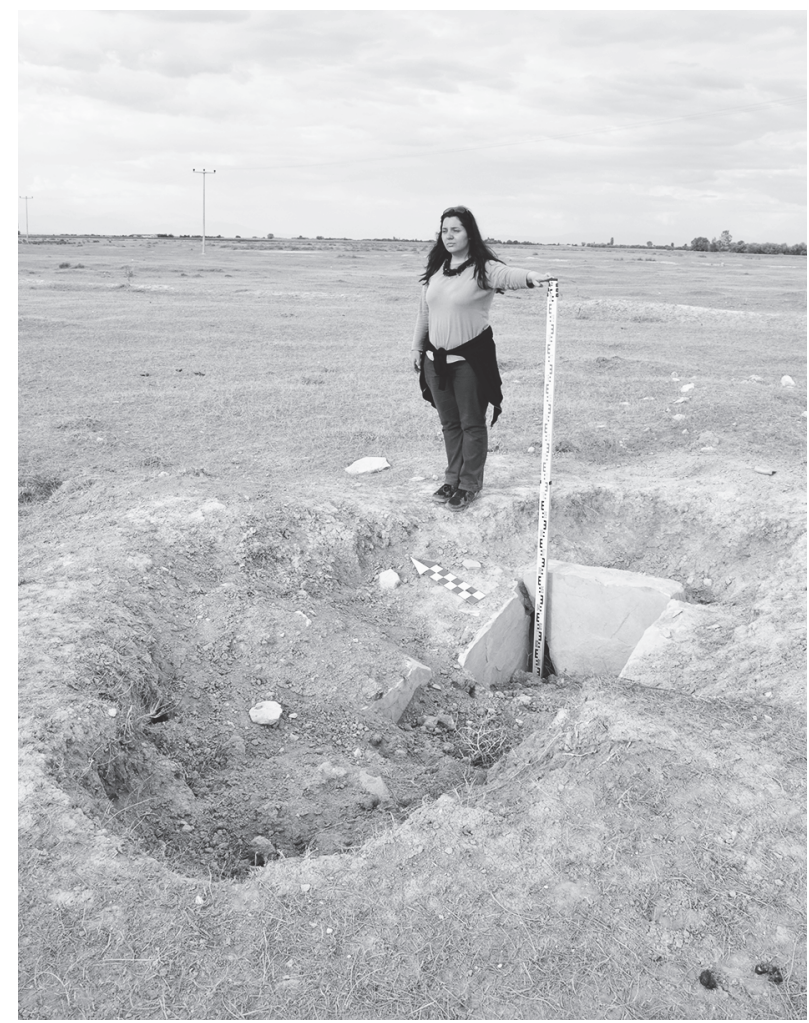

Fig. 28 : Adalıyer Mevkii Yerleşimi Roman cist grave.

\section{Asar Mevkii Kale Yerleşimi}

(Map 1 No 34, Fig. 30)

This hilltop settlement respectively fortress, or rather castle, is on top of a steep hill (Fig. 30). It is $2.5 \mathrm{~km}$ northwest of Beyören Köy mosque. The castle is around half an hour walking distance from the village. On top are round cisterns and steps carved into the rock. The settlement is fortified, and remains of the foundations are visible. The stones used were quarried from the hilltop. Within the wall are rectangular and oval building structures. There are several illicit excavations, and in one of them a capital was discovered. The pottery seems to be mainly Late Antique and Byzantine. Since this period is not included in our permit, we couldn't conduct any further investigations.

In Beyören village several Late Antique and Byzantine blocks were used as spolia in houses and also in the mosque (Beyören Köy Camii). Some of them have crosses depicted on them. Also next to the mosque was a set of Roman millstones (meta and catillus), as was discovered in Taştepepe Obası in $2013^{31}$ and the cemetery of Çiller village in $2014^{32}$.

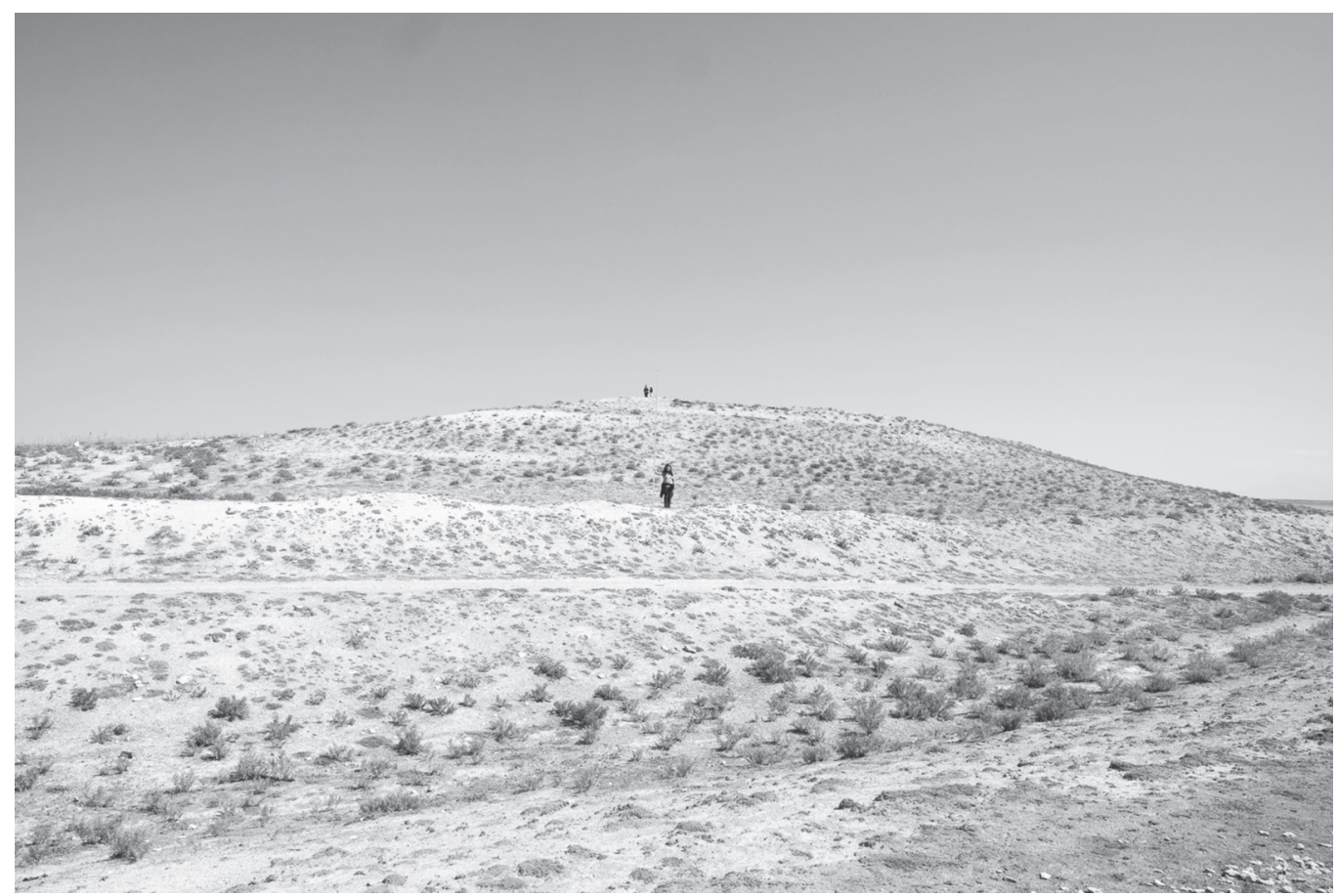

Fig. 29 : Başin Yaylası Höyük.

31) Maner 2014: 358 Fig. 28-29.

32) See above. 


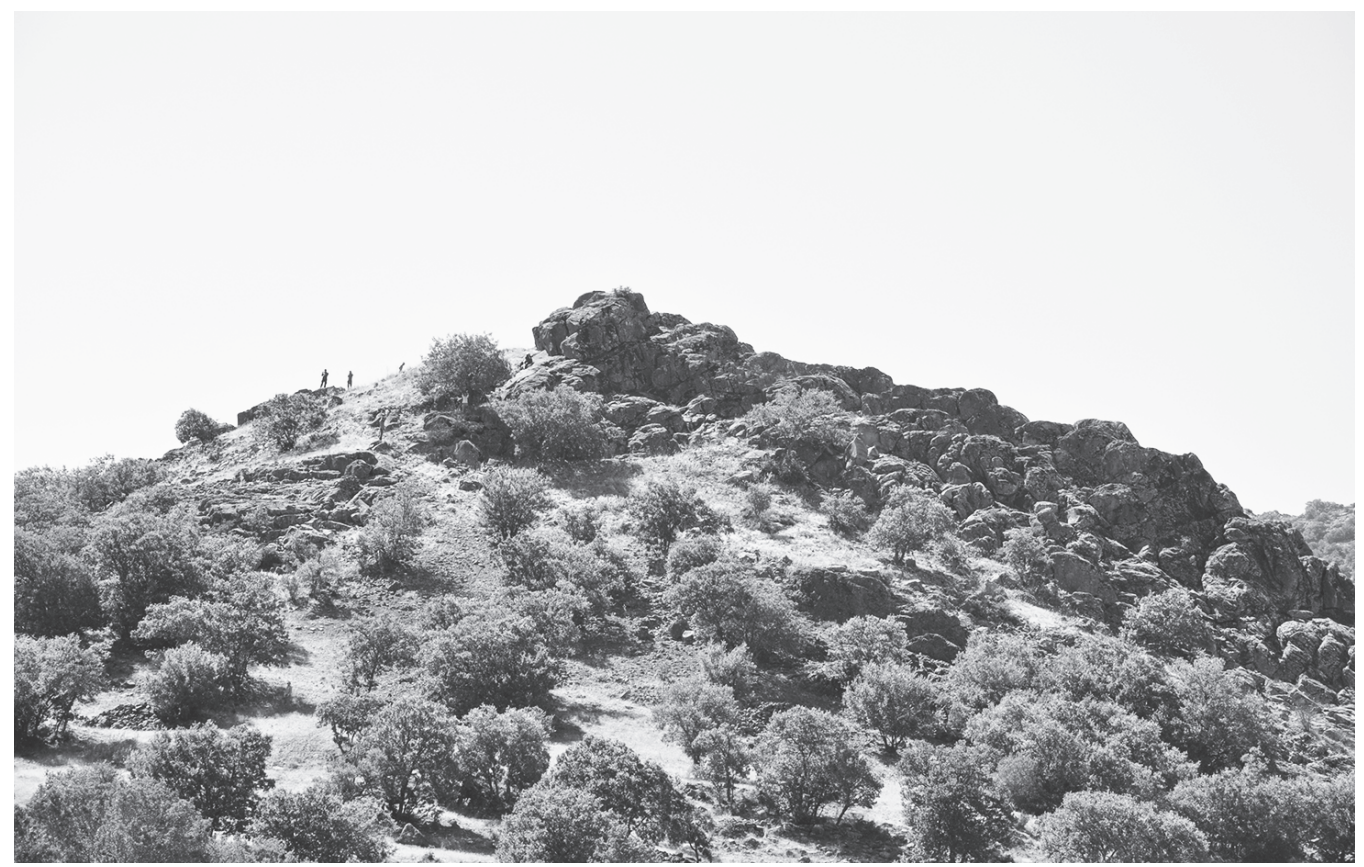

Fig. 30 : Asar Mevkii Kale Yerleşimi.

\section{İbizlik Kalesi Örenyeri (Çekin Kalesi) \\ (Map $1 \mathrm{~N}^{\circ}$ 35, Fig. 31-33)}

İbizlik Kalesi Örenyeri (also known as Çekin Kalesi by local people) lies $6.5 \mathrm{~km}$ southeast of Kutören, which is a village $37.5 \mathrm{~km}$ north of Ereğli. It is located inside the fertile Çekin valley (Fig. 31) and controls the whole plain, including important road networks, such as to Tyana (modern Kemerhisar, Hittite Tuwanuwa) in the west, Aksaray in the north, and the Cilician Gates and the Taurus Mountains in the south. It is a fortress built on a natural, shallow rock. The fortress stretches from northwest to southeast and is (N-S) $215 \mathrm{~m} \mathrm{x}(\mathrm{E}-\mathrm{W}) 108 \mathrm{~m}$, occupying an area of around 23.2 ha. The whole site was once fortified with a cyclopean wall. The fortress is built of a dark grey-blackish stone, which shines in the sun like silver. It is probably some kind of volcanic stone. The northern portion is the highest part (around $6 \mathrm{~m}$ high) of the fortress (Fig. 32). The fortification walls are built around a rocky outcrop, and some wall portions are still standing in the northern section, where they are around 1-2 $\mathrm{m}$ high with 3-4 courses preserved. The rest of the walls are destroyed and the boulders are scattered across the site. The fortification walls of the southern part are

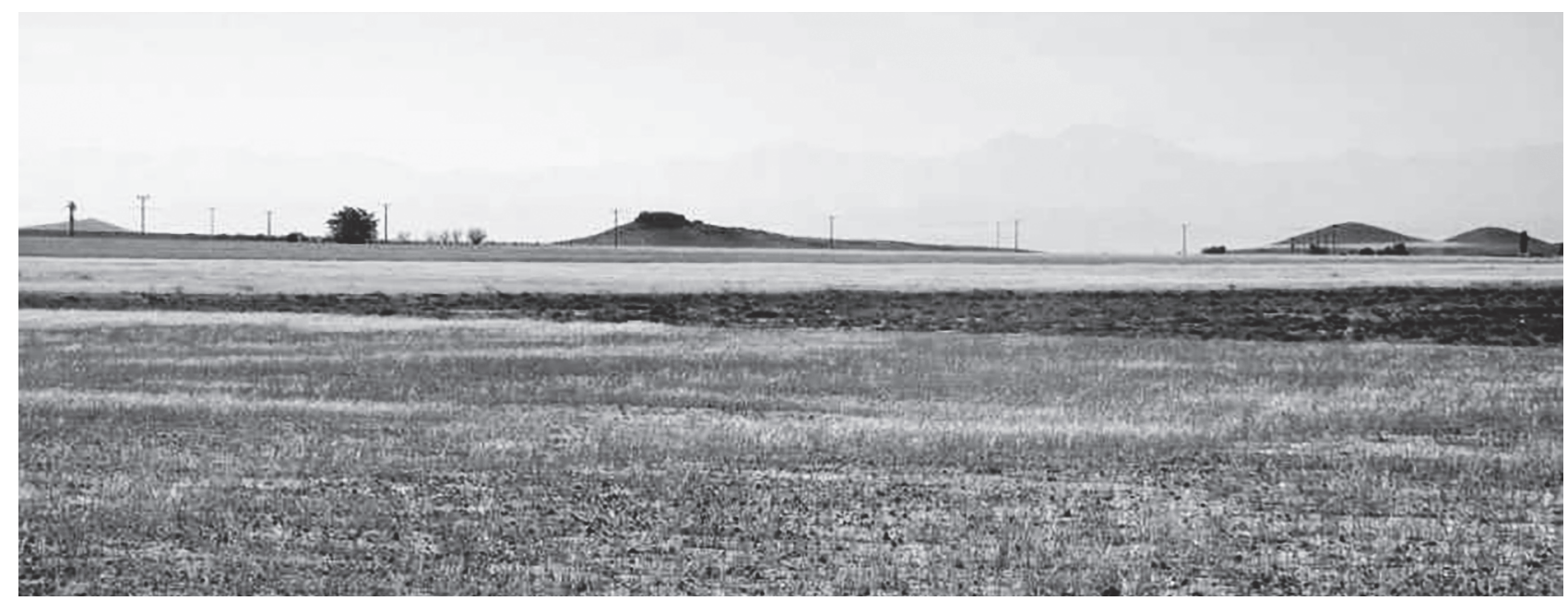

Fig. 31 : İbizlik Kalesi Örenyeri (from South). 


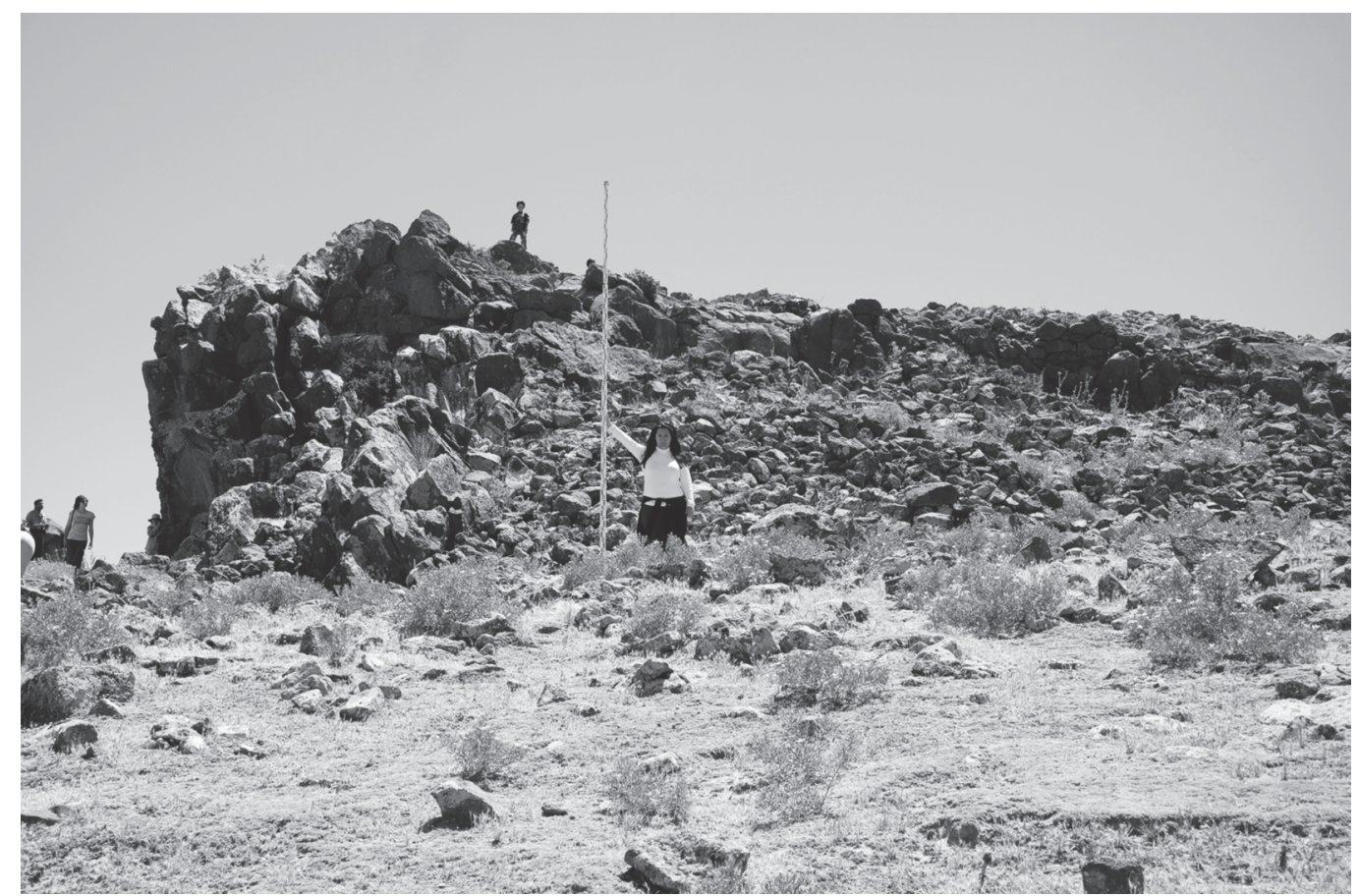

Fig. 32 : İbizlik Kalesi Örenyeri Acropolis.
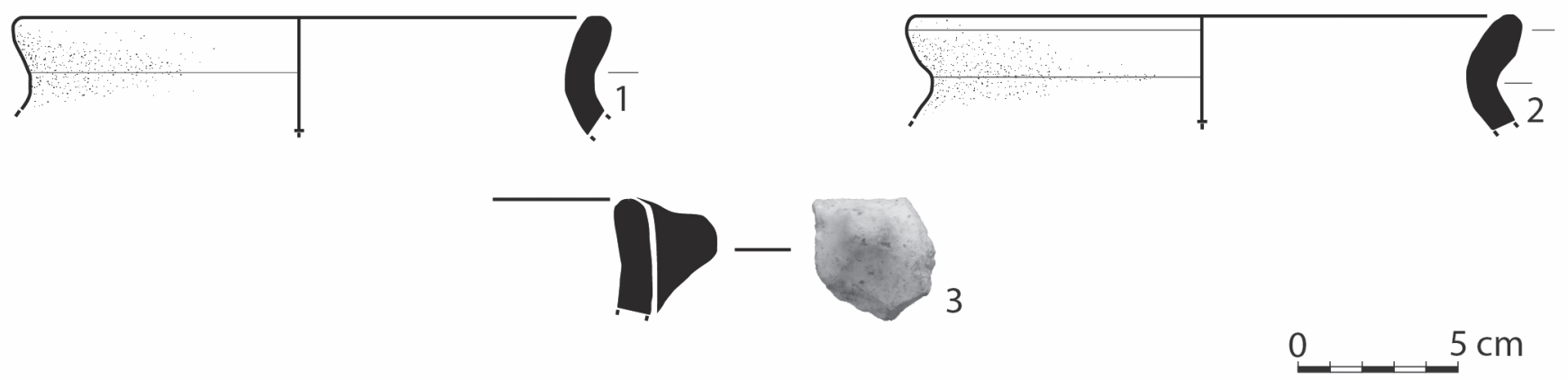

Fig. 33 : İbizlik Kalesi Örenyeri (Çekin Kalesi) pottery samples.

practically all destroyed, and here the stones are also widely scattered. The local villagers told us that they used the stones to build their houses and removed many from the site.

However, on the western side, an $8 \mathrm{~m}$ long section of a wall is preserved to two courses. The boulders are $c a$. $0.8-1 \mathrm{~m} \times 0.6-0.8 \mathrm{~m}$ large and the wall is built with cyclopean masonry, which means that the interstices between the big boulders are filled with small stones. It seems like this wall belongs to a tower structure. This type of masonry was applied during the Late Bronze and Iron Ages. Likely, the fortification dates to one of these periods. Within the fortress are the remains of a $10 \mathrm{~m}$ x $10 \mathrm{~m}$ structure in the centre. There were so many stones scattered around the site that it was very difficult to determine buildings and structures.
The pottery from this site shows a long occupation period. There are examples from the Chalcolithic (Fig. 33: 3), Early, Middle, and Late Bronze Ages (Fig. 33: 1-2), Iron Age, Hellenistic, Roman and Byzantine periods.

\section{Obruk Höyük (Map 1 № 36, Fig. 34)}

Obruk Höyük (Fig. 34) is located under Obruk Village. The village and the mound are placed within a wide, natural cavity. The höyük is located within Obruk Yaylası and $5.8 \mathrm{~km}$ southeast of Çekin Kalesi. The ancient settlement has been registered since 1988. It is unfortunately not possible to determine the original size of the höyük, as it is used for habitation and the nature of the höyük is mostly lost. The preserved size of the höyük is approximately (N-S) $87 \mathrm{~m}$ x (E-W) $63 \mathrm{~m}$. However, the villagers 


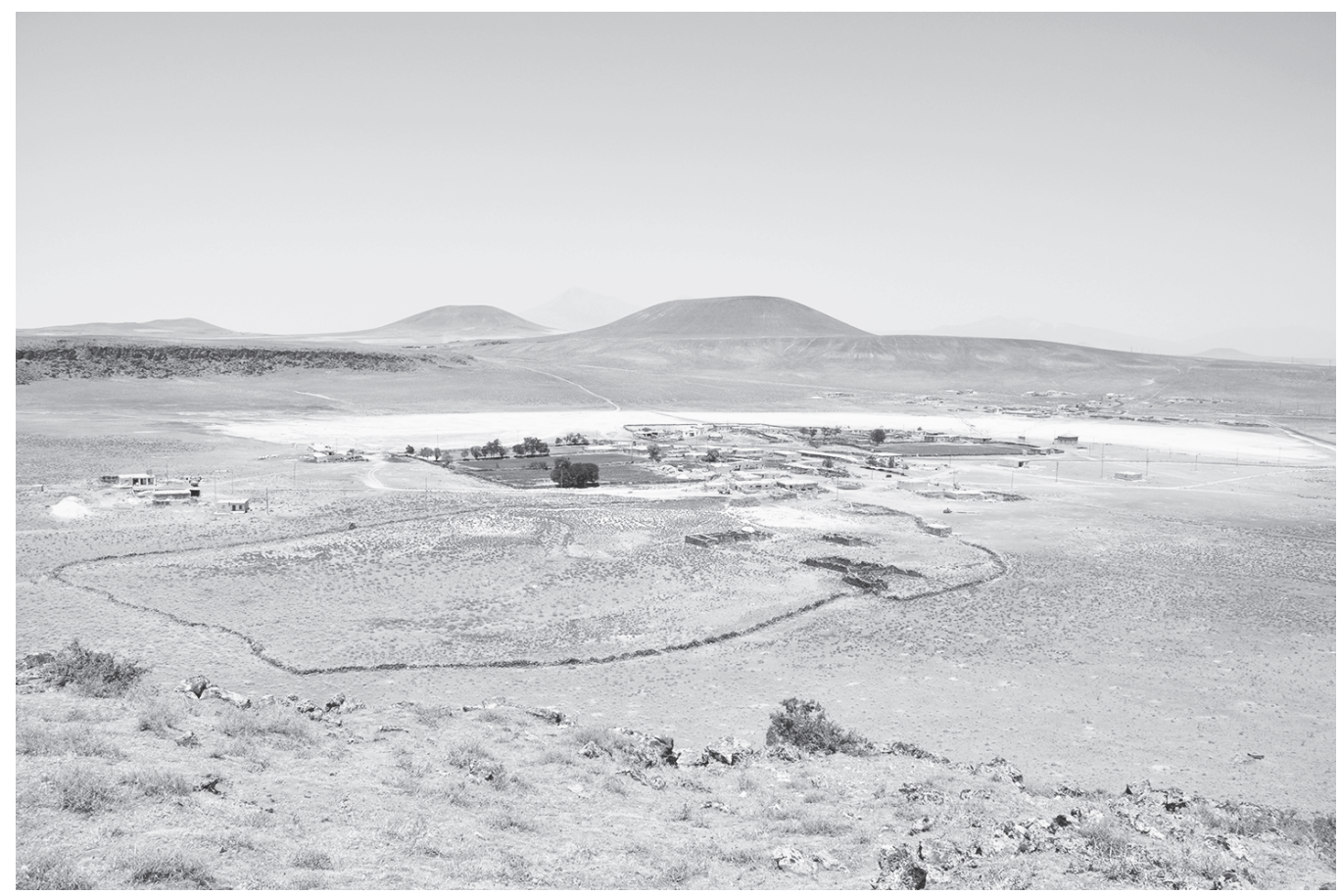

Fig. 34 : Obruk Höyük.

report that the höyük was previously much higher and wider. Only the remains of a slope are visible on the eastern part. The stones from previous settlements were used by the villagers to build their own houses. However, there is a stone building built with grey stone, probably basalt, with an arched roof. This structure probably dates to Late Antiquity. On the eastern slope are the remains of a road, which is around $4.5 \mathrm{~m}$ wide and preserved for about $218 \mathrm{~m}$. The few collected pottery sherds date to the Early-Middle-Late Bonze Ages, Middle Iron Age and Roman period.

\section{Karaağıl Örenyeri (Maşatca Höyük)}

(Map $1 \mathrm{~N}^{\circ}$ 37, Fig. 35)

Karaağ1l Örenyeri (Fig. 35) is also known as Maşatca Höyük and has been registered since 1988. The höyük is located within fertile fields $800 \mathrm{~m}$ southeast of Karaağıl Yaylası, and hence the slopes of the ancient settlement mound are also used for agriculture. The top is still in use as a cemetery. According to the villagers, the cemetery was placed here one hundred years ago. The graves are made of unworked, medium-sized boulders, which were probably taken from architectural remains. Upon our arrival, no architectural remains were discovered. The höyük is (N-S) $90 \mathrm{~m} \times(\mathrm{E}-\mathrm{W}) 90 \mathrm{~m}$ large. The pottery dates mainly to the Late Bronze Age and Middle Iron Age.
Cihan Kalesi (Map $1 \mathrm{~N}^{\circ}$ 38, Fig. 36)

The fortress (Fig. 36) is located $12 \mathrm{~km}$ southeast of Kutören, $5.7 \mathrm{~km}$ southeast of Ibizlik Kalesi Örenyeri and just $1 \mathrm{~km}$ west of Obruk village. Built on an elevation and controlling the whole plain, It is a smaller fortress than Ibizlik Kalesi Örenyeri, although much better preserved. The walls of the fortress are also made of cyclopean masonry with slightly-worked stone boulders. The fortress is (N-S) $53 \mathrm{~m} \mathrm{x}(\mathrm{E}-\mathrm{W}) 79 \mathrm{~m}$ large. The well preserved entrance is in the west and is a direct access gate. The foundations of the room walls inside the fortress are partially preserved. On the northeastern slope are partially preserved steps going down the hill. $1.6 \mathrm{~km}$ northeast of the fortress is a small cemetery with ovoid graves which are marked with stones. Among the collected pottery were fragments from the Middle Bronze Age, Middle Iron Age, Hellenistic, Roman and Byzantine periods.

\section{Sarıçören Kalesi (Map 1 № 39)}

This castle is $3.9 \mathrm{~km}$ northwest of Belkaya village, $3.5 \mathrm{~km}$ east of Mount Arısama (also known as Kötü Dağ) and is located on its western hilltop. According to the muhtar of Belkaya, the first settlement of Belkaya was located here. Upon arrival, many house foundations and a village cemetery were visible. The cemetery is surrounded with a fence. Within the old, abandoned village, a rock 


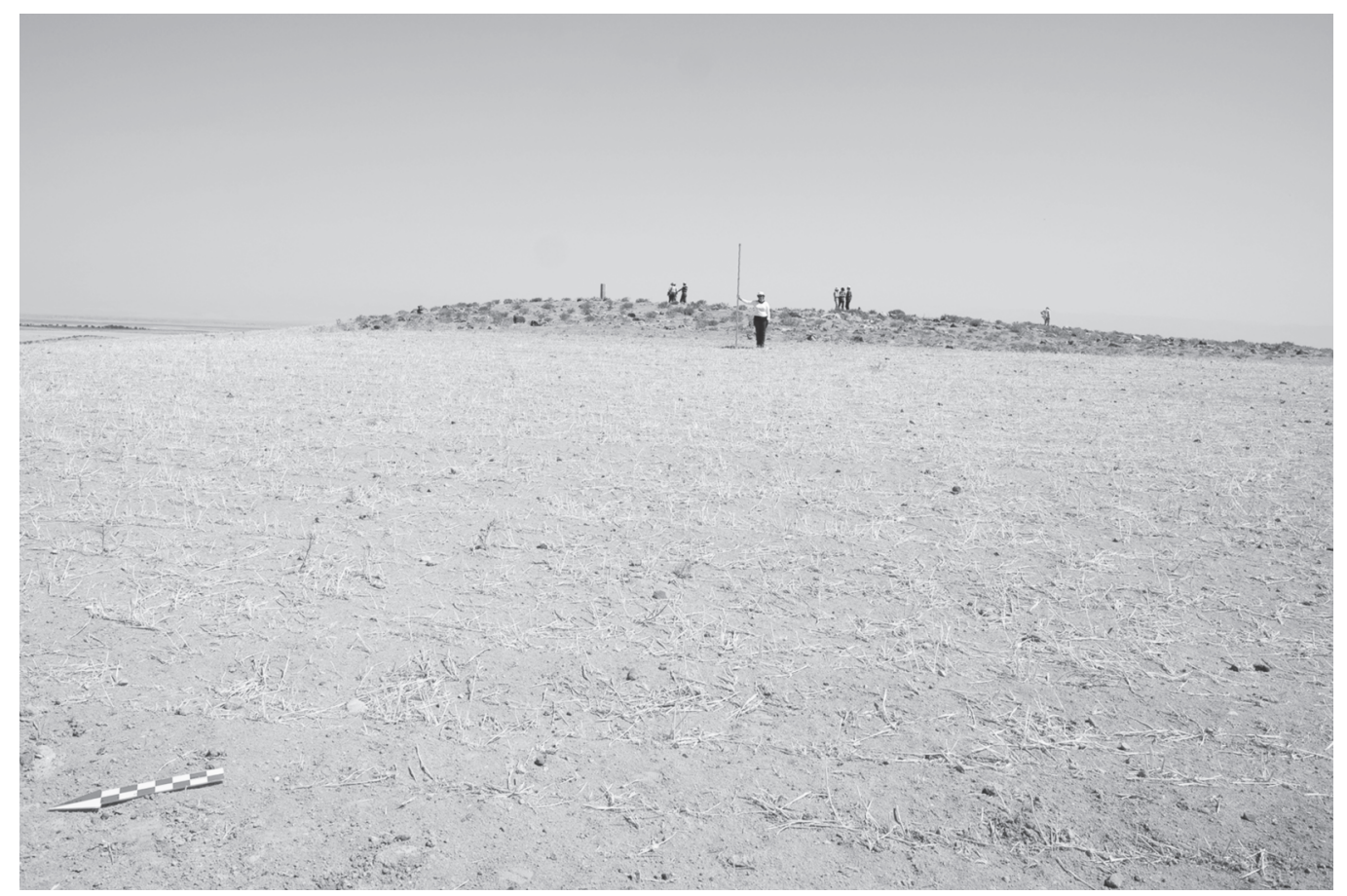

Fig. 35 : Karaağıl Örenyeri (Maşatca Höyük).

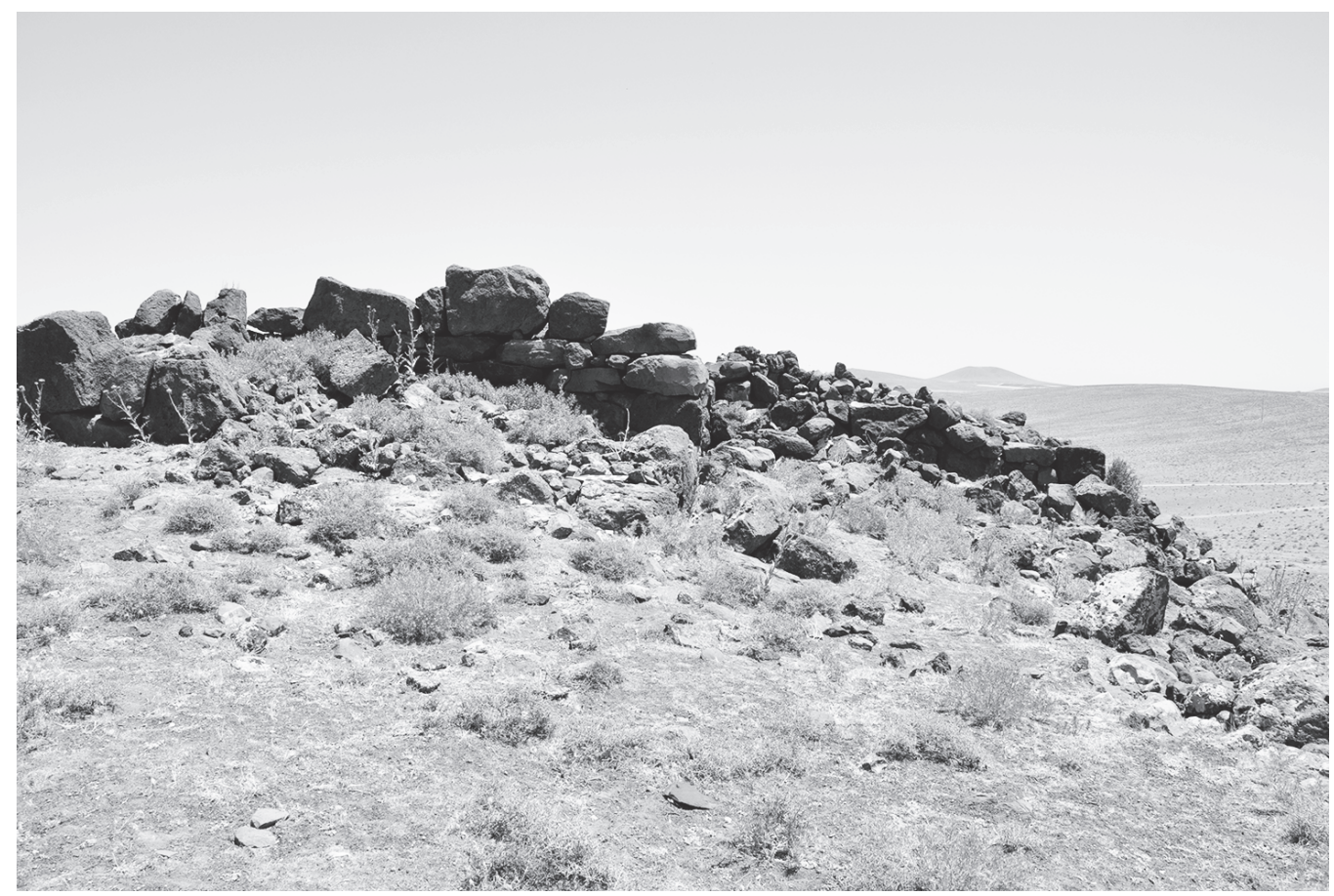

Fig. 36 : Cihan Kalesi. 
massif was observed. Interestingly, it is surrounded with a wall built of huge boulders, the foundations of which are visible among the high grass. The construction also has an entrance. $5 \mathrm{~m}$ west of the construction was a boulder with square lewis holes. This technique was generally used in the Iron Age. $200 \mathrm{~m}$ north of this is a rock massif where there were the possible remains of a castle which is known as Sarıçören Kalesi by the locals.

Unfortunately, the weather conditions were not good and, since it was the end of the survey season, we decided to return in the 2015 survey season to conduct more detailed investigations.

\section{Tont Kalesi (Map 1 № 40, Fig. 37-38)}

Tont Castle (Fig. 37) is $1.9 \mathrm{~km}$ southeast of Gökçeyazı village, $2.6 \mathrm{~km}$ north of the Ivriz dam and $5.8 \mathrm{~km}$ north of the Neo-Hittite water sanctuary of Ivriz. It has been a registered settlement since 1988. The settlement is located on a hilltop which extends from west to east. The western part of the settlement was partially removed and damaged because it was used as a stone quarry. Again, the top of the western part was dynamited, which has led to destruction on the top of the castle. The hilltops $0.7 \mathrm{~km}$ and $1.8 \mathrm{~km}$ west of Tont Castle are used as stone quarries.
The site consists of a castle and a settlement. The settlement is located north of the castle, down the slopes of the hill, and foundations of buildings are visible among the grass. The castle (to the south) is built around the highest peak of the hilltop (Fig. 37). There are steps going up to the peak. However, they were not very solid, and it was too dangerous to climb up. The walls of the castle seem to date to Late Antiquity, because they are made with white mortar. About $70 \mathrm{~m}$ north of the castle are the foundations of a building with twelve rooms visible. The building is (N-S) $170 \mathrm{~m} \times(\mathrm{E}-\mathrm{W}) 100$ $\mathrm{m}$. The walls are partially preserved up to two courses and are made of cyclopean masonry. Slightly-shaped boulders were used. The remains and masonry are reminiscent of Hittite buildings, although the pottery from within the rooms was mainly green glazed, and therefore probably Byzantine. Down the slopes in the northwest were the foundations of several buildings among high grass. Among the pottery from the southern part of the settlement were sherds from the Chalcolithic, Early (Fig. 38:3, 4) - Middle (Fig. 38: 6) - Late Bronze Ages (Fig. 38: 1, 2), Iron Age (Fig. 38: 5), Hellenistic, Roman, Byzantine and perhaps Seljuk periods. Among the Middle Bronze Age pottery were basket handles

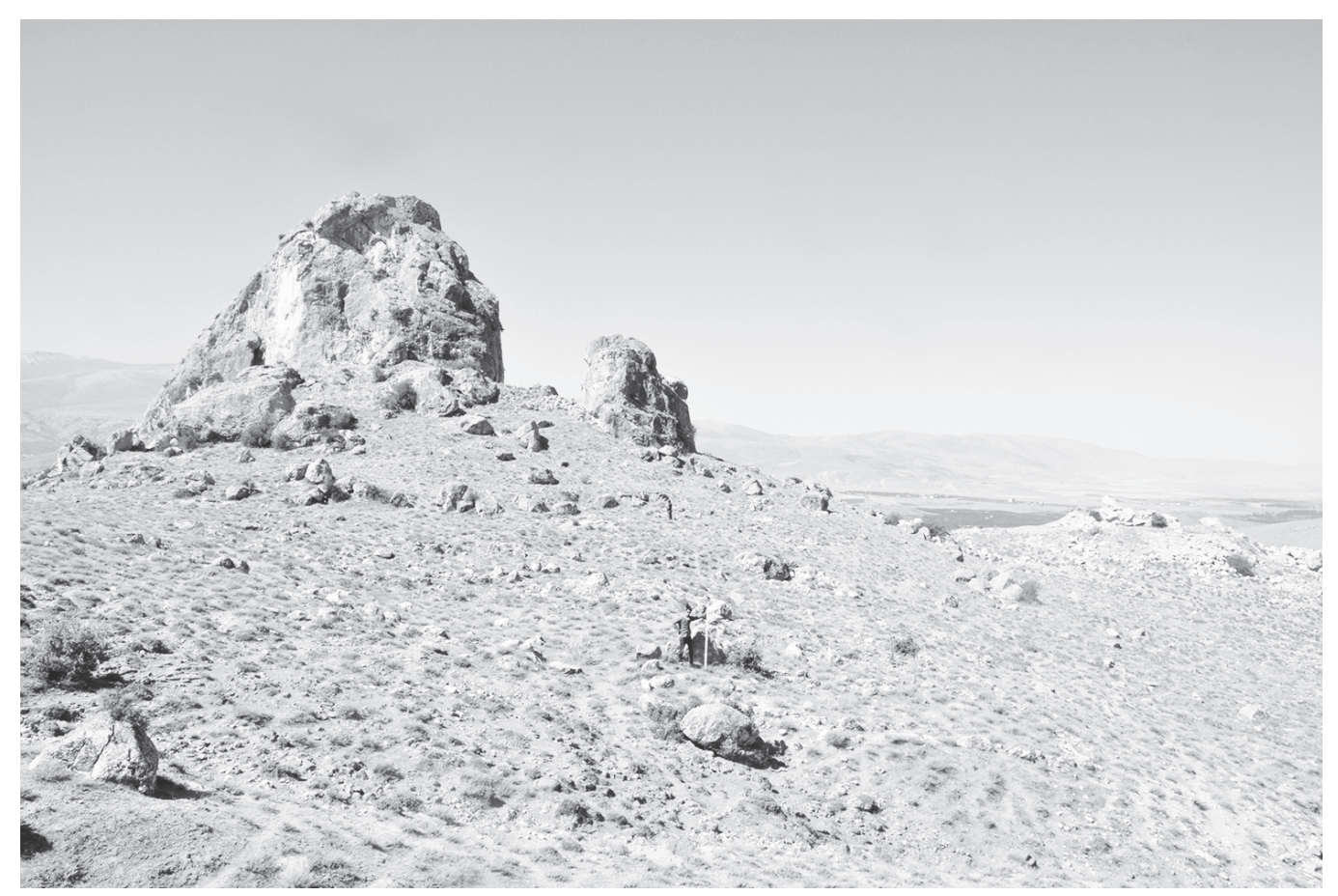

Fig. 37 : Tont Kalesi. 

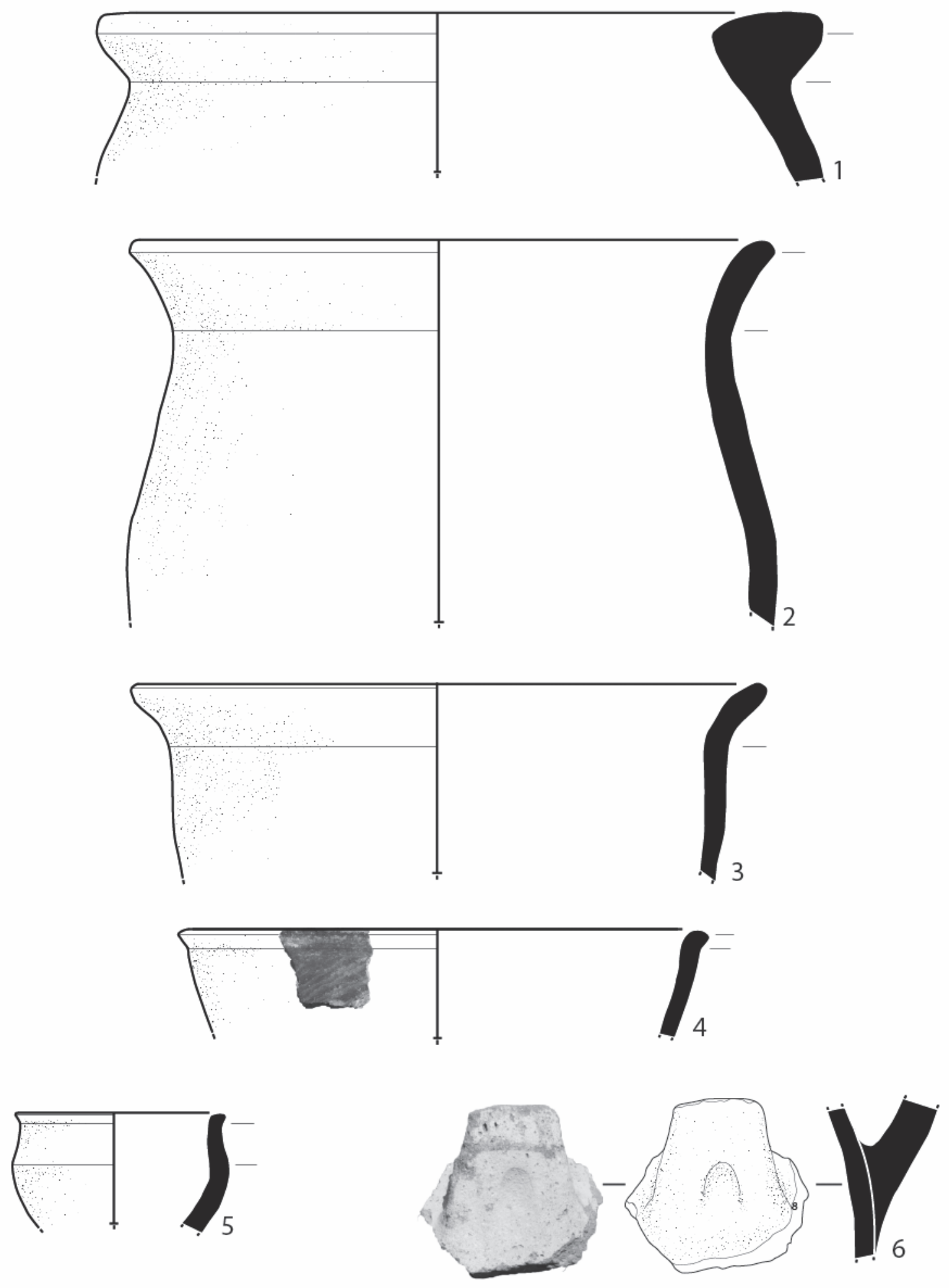

O $\quad 5 \mathrm{~cm}$

Fig. 38 : Tont Kalesi pottery samples. 
fragments (Fig. 33: 6) with finger prints at the bottom part, like they have been found in Çiller Höyük ${ }^{33}$.

Tont Kalesi is, according to Tabula Imperii Byzantini, the town of Heracleia ${ }^{34}$. Heracleia is the successor settlement of Kybistra. Kybistra was the hometown of St. John "in puteo". In some cases the two town names (Heracleia Kybistra) also appear together as a compound name. In 708 A.D. the town was conquered by the Arabs and was renamed Hiraqla ${ }^{35}$. Kybistra derives from the Hittite toponym Hupišna/Hubišna ${ }^{36}$. Hupišna/Hubišna is mentioned in the Old Assyrian texts ${ }^{37}$ and was conquered in the Old Hittite Period by the Hittite king Labarna I, who understood that it had an important strategic location $^{38}$. Mellaart argued that Ereğli Karahöyük is the Hittite town of Hupišna/Hubišna ${ }^{39}$. However, if Kybistra is linguistically equated with Hupišna/ Hubišna, and Kybistra is located in Tont Kalesi, it would be possible to assume that Tont Kalesi is the Hittite town of Hupišna/Hubišna. Hence, Ereğli Karahöyük must be another Hittite town.

\section{Eskikışla Dikili Taş Mevkii Yerleşmesi (Map $1 \mathrm{~N}^{\circ}$ 41)}

At the beginning of the $20^{\text {th }}$ century, four inscribed altars from Emirgazi were shipped to the Istanbul Archaeological Museums ${ }^{40}$. These Hittite altars were found in Kıçıkışla (today Eskikışla) in a secondary context, west of Arısama Dağ. A short visit was paid to Eskikışla towards the end of the survey season to determine if it would be possible to find the spot where the Hittite altars were discovered and also to plan the next survey season, which will investigate parts of Emirgazi, specifically the region around and on top of Arısama Dağ. Today Eskikışla is used only as a habitation place during the summer. The small village is around $4.2 \mathrm{~km}$ north of Emirgazi, $2.8 \mathrm{~km}$ west of Arısama Dağ and is divided by a road. The western part was inhabited during the first half of the $20^{\text {th }}$ century and the eastern part from the second half of the $20^{\text {th }}$ century onwards. When we arrived, only three families were living there, pasturing their animals. One of the family members (around 55 years old) remembered from his grandfather's stories about the altars standing next to a water spring in the western part of the village.

He showed us settlement remains $1.9 \mathrm{~km}$ west of Arısama Dağ in a place known as Eskikışla Dikili Taş Mevkii. The grass was very high, which made investigation and surveying almost impossible, so we decided to postpone the research of this area until 2015.

\section{Maltepesi Höyük (Map 1 № 42, Fig. 39)}

Maltepesi Höyük (Fig. 39) is located on the southwestern slope of Mount Arisama, in the Kale district of the Emirgazi province, $1.2 \mathrm{~km}$ north of the main mosque. The höyük is (N-S) $210 \mathrm{~m} \mathrm{x}$ (E-W) $170 \mathrm{~m}$ large and is $7 \mathrm{~m}$ high. There are several rock outcrops on the surface, although no architectural remains or worked stone boulders or slabs were seen. The pottery dates to the Early Bronze Age, Middle Iron Age, Hellenistic and Roman periods.

Osman Köseli Höyük (Map 1 No 43, Fig. 40)

Osman Köseli Höyük is the only registered höyük in the Halkapınar province. The settlement mound is $3.65 \mathrm{~km}$ northeast of Seydifak1lı village. The höyük and the surrounding area are used for agriculture. During the survey, high grass and crops made it difficult to find pottery and also to determine the size of the mound. The mound is $c a$. (N-S) $130 \mathrm{~m} \times(\mathrm{E}-\mathrm{W}) 160 \mathrm{~m}$ large and around $1.5-2 \mathrm{~m}$ high. According to villagers, agricultural acitivities removed several layers from the top of the mound, meaning that originally the mound was higher and probably also wider. The collected pottery dates to the Chalcolithic, Early Bronze Age, and Middle Iron Age.

33) See above. These types of handles have been also found in Beycesultan. Abay and Dedeoğlu 2009: 79 Fig. 6.

34) Hild and Restle 1981: 188-189.

35) Loc. cit.

36) Loc. cit.

37) Barjamovic 2011: $236 \mathrm{n} 898$.

38) Garstang and Gurney 1959: 16, 72; Kessler 1975.

39) Mellaart 1955: 117: Kessler 1975. Museum.

40) Today they are on display in the Ancient Near Eastern Museum (Eski Şark Eserleri Müzesi) within the Istanbul Archaeology 


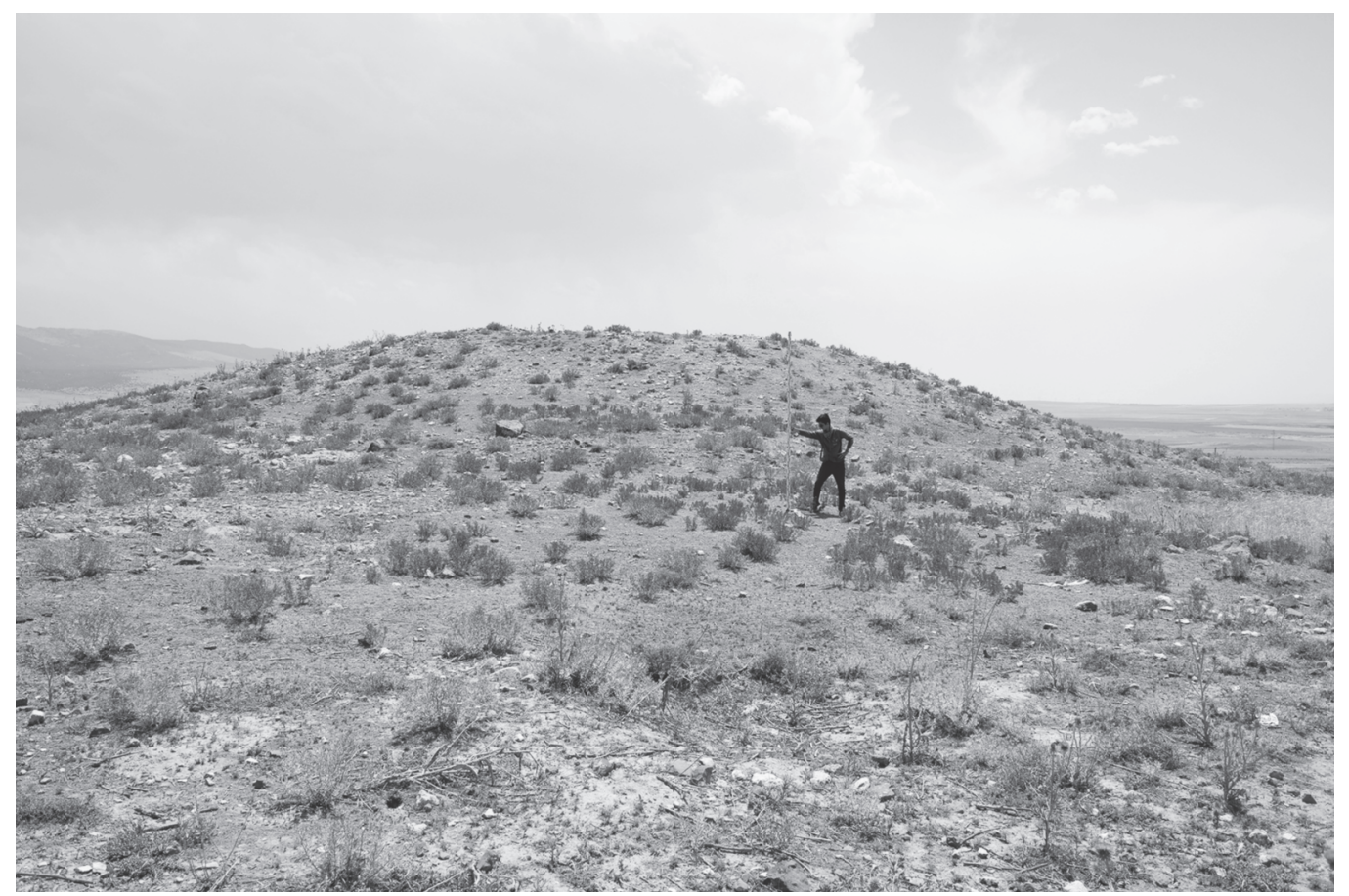

Fig. 39 : Maltepesi Höyük.

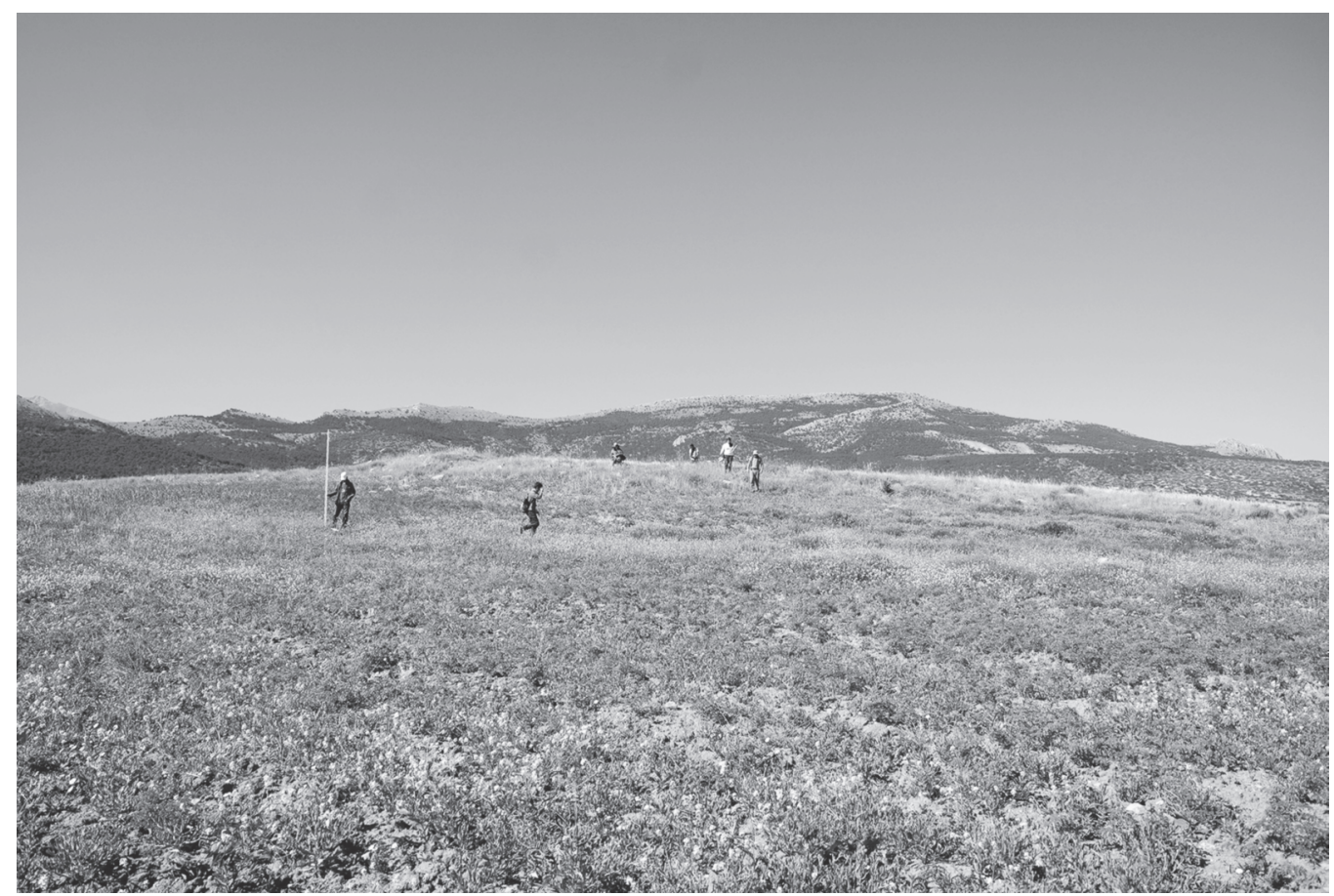

Fig. 40 : Osman Köseli Höyük. 


\section{CONCLUSION AND FUTURE WORK}

The 2014 survey has added a fourth type of settlement to the three previously designated types in 2013 (mounds, flat settlements, hilltop) ${ }^{41}$, namely fortresses respectively castles. The survey also showed that it is absolutely necessary for the Roman period of this region to be investigated by a specialist, as there are many Roman settlements. In 2015, the eastern corner of Ereğli around Akgöl and the northeastern portion (east of Kutören, west and north of Belkaya) will be surveyed. In addition, the survey of Emirgazi and Mount Arisama will start in 2015 and will be hopefully continued in 2016 .

Ç. M.

\section{BIBLIOGRAPHY}

Abay, E. and Dedeoğlu, F., 2009: "Beycesultan 20072008 Yılları Kazı Çalışmaları Ön Raporu”, Arkeoloji Dergisi 13: 54-79.

Barjamovic., G., 2011: A Historical Geography of Anatolia in the Old Assyrian Colony Period, Copenhagen.

Dupré, S., 1983: Porsuk I: La céramique de l'Age du Bronze et de l'Age du Fer, Paris.

Garstang, J. and Gurney, O. R., 1959: The Geography of the Hittite Empire, London.

Güneri, S., 1989-91: "'Orta Anadolu Höyükleri, Karaman-Ereğli Araştırmaları”, Türk Arkeoloji Dergisi 2829: 97-114.

- 1990: "Orta Anadolu Höyükleri, Karapınar, Cihanebyli, Sarayönü, Kulu Araștırmaları”, AST 7: 323339.

Hil, F. and Restle, M., 1981: Kappadokien (Kappadokia, Charsianon, Sebasteia und Lykandos, TIB 2, Wien.

Kessler, K., 1975: "Hupišna" Reallexikon der Assyriologie, Vierter Band Ha-a-a-Hytaspes: 500.

Maner, C., 2014: "Preliminary Report on the First Season of the Konya-Ereğli (KEYAR) Survey 2013", Anatolia Antiqua XXII: 343-360.

- 2015a: "Hethitische Funde im Museum von Ereğli und ihre Bedeutung für die hethitische Präsenz in dieser Region", Istanbuler Mitteilungen 64: 207-221.
- 2015b: "Konya ili Ereğli, Halkapınar, Karapınar ve Emirgazi 2013 Yı1ı Yüzey Araştırmaları (KEYAR)", AST 32/1: 27-46.

- in print: "Hittite Remains in Ereğli Kara Höyük", in Alparslan, M., Doğan Alparslan, M. (eds.), Hittite Places and Spaces. International conference proceedings.

Mellaart, J., 1954: "Preliminary Report on a Survey of Pre-Classical Remains in Southern Turkey", Anatolian Studies 4: 175-240.

- 1955: "Iron Age Pottery from Southern Anatolia", Belleten 19: 115-136.

- 1958: "Second Millenium Pottery from the Konya Plain and Neighborhood", Belleten 22: 311-345.

- 1963: "Early Cultures of the South Anatolian Plateau, II: The Late Chalcolithic and Early Bronze Ages in the Konya Plain", Anatolian Studies 13: 199-236.

Osten, H. H. von der 1937: The Alishar Hüyük Seasons of 1930-32, Part 1, Chicago.

Özgüç, T., 2003: Kültepe Kanis / Nesa: The Earliest International Trade Center and the Oldest Capital City of the Hittites, Japan.

Schmidt, E. F., 1932: The Alishar Hüyük 1928/29, Chicago. 


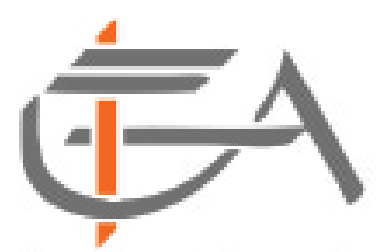

Institut Français d'Etudes Anatoliennes

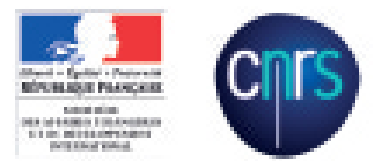

Eglise paléochrétienne de Bindéos (Pisidie), détail de la mosaïque ornant le sal de la nef centrale, $4^{e} \mathrm{~s}$. ap. J.-C. 